\title{
Arctic Oil and Public Finance: Norway's Lofoten Region and Beyond
}

\author{
Klaus Mohn*
}

\begin{abstract}
This study explores potential implications of Arctic oil and gas exploration for public finance, with the Norwegian Lofoten region as a valuation case. A model is calibrated to turn oil and gas resource estimates into projections for investment, production, and net cash flows, which are discounted to assess the direct impact for the government budget. With the Norwegian oil fund mechanism and fiscal policy rule, Lofoten oil and gas revenues could add fiscal capacity in the range of 0.1-2.4 per cent of the current government budget, implying a permanent increase in annual government spending (or tax relief) of 24-220 USD per capita. Corresponding implications for other resource-rich countries in the Arctic depend on their resource potential and the relative role of oil and gas in their economy.
\end{abstract}

Keywords: Petroleum economics, Resource revenue management, Public finance

https://doi.org/10.5547/01956574.40.3.kmoh

\section{INTRODUCTION}

The Arctic holds a substantial potential in terms of petroleum resources. According to the USGS (2008), more than 400 billion oe of oil and natural gas are yet to be discovered in this part of the world. Managed properly, these resources can be converted to reserves, revenues, and financial wealth for the host countries. And if governments are successful in the capture of resource rents, significant gains could arise for the general public of resource-rich countries, via government spending and/or tax relief.

At the same time, Arctic oil and gas resources involve substantial challenges and dilemmas, and development so far has been sluggish (Henderson and Loe, 2014). Poorly mapped offshore resources in a demanding climate, technology requirements, infrastructure investment, and stakeholder management are elements that contribute to the cost and risk of Arctic oil and gas exploration. Late developments for energy and climate policies are also not in favour of large-scale oil and gas operations in the Arctic, adding skepticism and controversy to the issue.

Norway's Lofoten region is an appropriate example. ${ }^{1}$ With a significant resource potential, the waters off the coast of the Lofoten region are viewed as highly attractive by the oil companies. Although the underground uncertainty is high, resource values are most likely substantial, judged not only by estimates from the Norwegian Petroleum Directorate (NPD; 2010), but also by the interest from the oil industry.

1. What I refer to as the Lofoten region is normally split into three separate sub areas, referred to as Lofoten, Vesterålen, and Senja. For simplicity of exposition, I will collapse the reference to these three areas to 'the Lofoten region'.

* University of Stavanger Business School, 4035 Stavanger, Norway (klaus.mohn@uis.no).

The Energy Journal, Vol. 40, No. 3. This is an open access article under the terms of the Creative Commons Attribution License (CC-BY), which permits use, distribution and reproduction in any medium, provided the original work is properly cited. All rights reserved.. 


\section{Figure 1: The Lofoten offshore region}

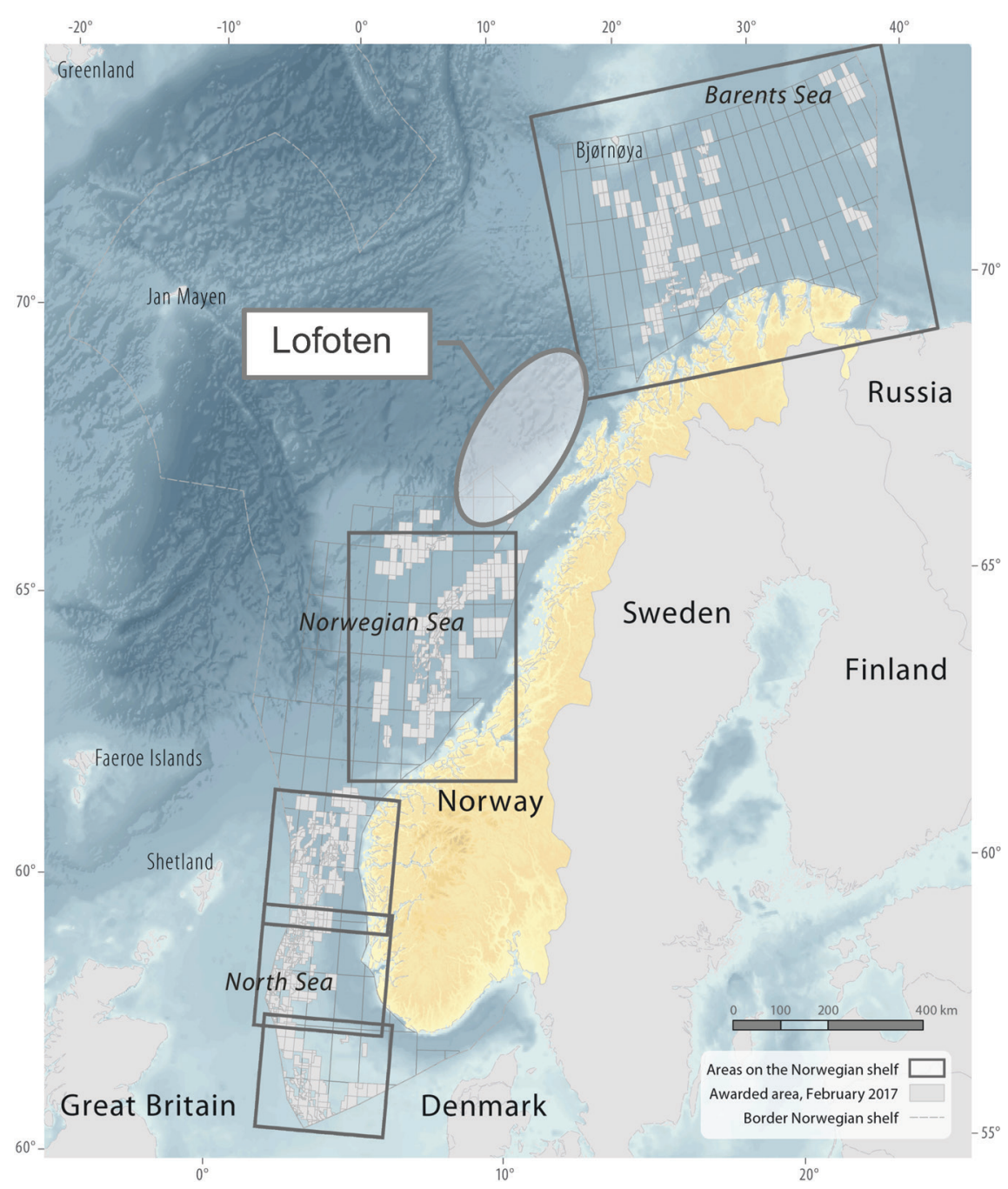

Source: Norwegian Petroleum Directorate.

Awards of virgin exploration acreage to oil companies who are short on exploration acreage and investment opportunities can provide activity and employment, and stem the expected stagnation on the Norwegian Continental Shelf (NCS). Industry interests also argue that Lofoten oil and gas activities could add large revenues to government budgets, and leave a potential for more government spending, and/or future tax relief.

An opening of the Lofoten region for oil and gas activities will require a full public impact assessment. The decision to start this process is still pending. At the same time, skepticism and resistance against further oil industry expansion is gaining strength in the Norwegian public. The Lofoten region has significant symbolic value for its regional fisheries, tourism activity, and recreational services (e.g., Navrud et al., 2016). Questions are also raised if Arctic oil exploration can possibly be combined with a forward-leaning attitude to climate policies. A recent national opinion 
poll indicates a 58 per cent majority in the Norwegian electorate against opening, ${ }^{2}$ and to many the fate of the Lofoten region is currently seen as a watershed for Norway's future role in the world of energy and climate policies (e.g. Milne, 2017). ${ }^{3}$

Estimates of economic values involved by oil and gas exploration form an important part of the information set of policy-makers. This study proposes a methodology to assess the net present values implied by direct revenues and costs relating to oil and gas activities in the Lofoten region, which also can be applied for other oil and gas provinces. I consider value drivers that normally enter decisions among oil companies who plan for exploration and extraction activity in the area. Indirect economic effects and external effects are therefore not part of this study. A full economic impact assessment would have to consider net present values reflecting ripple effects and external costs and benefits both on the regional and the national level (Fjose et al., 2012, Cappelen et al., 2012), including net impact on other industries (e.g., fisheries and tourism), potential local pollution and catastrophic risks for nature, ecosystems, recreational service provision (Loureiro and Loomis, 2012; Navrud et al, 2016), as well as costs of $\mathrm{CO}_{2}$ emissions and climate policies (e.g., Fæhn et al., 2017).

A full investigation of indirect and external costs and benefits go beyond the scope of this study, which is limited to direct economic effects, and in particular the implications for public finance. Even so, my approach may still prove useful point of departure for the evaluation of indirect and external effects both in Norway and elsewhere in the world. Specifically, if the sum of indirect and external costs falls short of the net present value of direct effects, the policy signal is that new oil and provinces in the Arctic could be opened. And conversely, if the net present value of indirect and external costs exceed net direct benefits, one should think twice before oil companies are let into the area.

A contribution of this study is the integration of resource valuation in a framework of resource revenue management and public finance, enabling an assessment of the financial contribution to public finance and fiscal capacity from a specific expansion of oil and gas exploration acreage. Building on previous theoretical work on resource revenue management (e.g., van der Ploeg and Venables, 2011; Venables, 2016), the impact on government budget capacity is assessed under a benchmark Permanent Income Hypothesis (PIH) approach and under a Bird-in-Hand (BIH) approach, the latter of which is a resemblance of the Norwegian model of resource revenue management.

I combine resource estimates from the Norwegian Petroleum Directorate (NPD; 2010) with economic theory and industry data to calibrate a cash flow model for oil extraction in Norway's Lofoten region. A generic model is calibrated to establish a Reference scenario for revenues and expenditures, which are then discounted to form net present value estimates for companies and for the government. The Reference scenario serves as a benchmark for subsequent sensitivity analyses and alternative scenarios. Under the Norwegian resource management model, valuation results are linked to public finance via the oil fund mechanism and the fiscal policy rule, to investigate the im-

2. The Norwegian Citizen Panel (2018) is a web-based survey of Norwegian opinions on important societal matters conducted twice a year by researchers at the University of Bergen (https://www.uib.no/en/citizen). Results from the latest rounds of interviews suggest that 58 per cent of the total population of Norway are against an opening of the Lofoten region for oil and gas activities. The resistance to oil activity in Lofoten is most pronounced in the younger part of the population and in the population of northern Norway. People in western Norway, who are more dependent on oil and gas activity, are somewhat less skeptical (see also Tvinnereim and Ivarsflaten, 2016).

3. When the liberal left (environmentalist) party was included in prime minister Erna Solberg's conservative/right government from January 2018, a agreement was formed not to make further evaluations and impact assessments of the Lofoten area for the coming 4-year period. 
plications for fiscal capacity, i.e. government spending and/or tax relief. Tentative implications for other resource-rich countries with territorial interests in the Arctic circle are then discussed in light of resource assessments by USGS (2008).

In terms of key results, this study suggests that the net present value of Lofoten oil and gas activities for the government could range from USD 4 bn to USD 40 bn (USD 15 bn in the Reference scenario), ${ }^{4}$ which again represents $0.4-3.7$ per cent (1.4 per cent) of the current value of the Norwegian oil fund (Government Pension Fund; GPF). Under the Norwegian fiscal policy rule, oil and gas extraction in the Lofoten region would allow the government to increase annual fiscal spending by NOK 3.6 bn (USD $450 \mathrm{M}$ ) in the Reference scenario, or to offer a corresponding amount in tax relief. In other words, the Reference scenario of this study suggests that the willingness to pay for protection of the Lofoten region at least will have to exceed NOK 521 (USD 65) per capita per year.

The assessment of direct economic resource values is laid out through the establishment of the Reference scenario in section two, with a calibrated model of revenues, expenditures, discounting procedures and senstivity analyses. Section three presents the implications for resource revenue management policies, public finance, and fiscal capacity, with an approximate extension to other resource-rich countries within the Arctic circle. Section four offers a discussion of indirect and external effects, whereas a summary and concluding remarks are offered in section five.

\section{VALUATION OF OIL AND GAS RESOURCES IN LOFOTEN}

\subsection{Resources and production}

The NPD's (2010) assessment of the resource potential of the Lofoten region is illustrated in Figure 2, with an estimate for expected resources accompanied by a P95 and a P05 estimate to reflect uncertainty. The expectation by Norwegian authorities is for a total volume of 1.3 bn boe, with oil (64 per cent) representing roughly twice the volume of expected gas resources. Note also that NPD's assessment is for resources to exceed $480 \mathrm{M}$ boe with a 95 per cent likelihood, and that the likelhood of a resource potential higher than 2.3 bn boe is limited to 5 per cent.

Building on the historical gradualism of exploration policies in Norway (Mohn and Osmundsen, 2008), an impact assessment in 2022/2023 could be followed by license awards in 2024, with exploration drilling commencing from 2025 and onwards. With idle capacity in supplier markets, lead times might be slightly lower than the historical average, and extraction is therefore assumed to start in 2031. With higher requirements for planning, investment and value-chain development, lead times of gas field discoveries are typically than for oil fields. Consequently, gas discoveries are expected to come into production in 2036, which is largely in line with lead times of previous discoveries of natural gas on the Norwegian Continental Shelf(NCS). These developments are approached through the modelling of two generic sample fields for oil and natural gas, establishing a reasonable benchmark for an extraction path which is consistent with NPD (2010) resource estimates. The model of this study is deterministic. The distribution over time of exploration activity, field development, and extraction is characterized by:

$$
f(\alpha)=\frac{1}{\alpha \sigma \sqrt{2 \pi}} e^{\left[-\frac{1}{2 \sigma^{2}}(\log \alpha-\mu)^{2}\right]},
$$

where $\alpha$ is the realisation of the exploration/development/extraction, whereas $\mu$ and $\sigma$ represent parameters of the time distribution. As the time resolution of this study is annual, discrete groups of

4. All conversions from NOK to USD of this paper assume an exchange rate of $8.00 \mathrm{NOK} / \mathrm{USD}$. 


\section{Figure 2: Lofoten: Estimates for recoverable oil and gas resources}

Billion barrels of oil equivalents

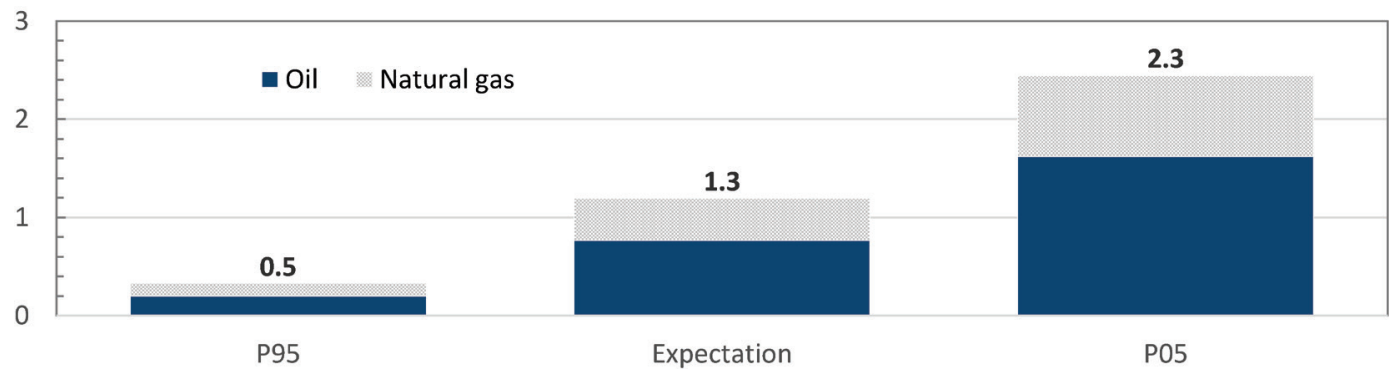

Source: Norwegian Petroleum Directorate (2010).

outcomes are formed for each year of the sampling period. Consider extraction from a stylised oil field as an example. Startup in 2031 and closedown in 2070 gives rise to 40 categories with successive ranking. Consequently, the share of total recoverable oil resources which is extracted in year $\mathrm{t}$ $\left(a_{t}\right)$ is approached via the following relationship:

$$
\alpha_{t}(\mu, \sigma)=\int_{\alpha_{t}}^{\alpha_{t+1}} f(\alpha \mid \mu, \sigma) \quad \forall t=2031, \ldots, 2070 .
$$

For each year in the sample, extraction of oil and gas $\left(q_{i t}\right)$ is now computed by multiplying annual share $\left(\alpha_{i t}\right)$ with the total volume of recoverable resources $\left(Q_{i}\right)$ :

$$
q_{i t}=\alpha_{i t}(\mu, \sigma) \cdot Q_{i}, i=\text { oil, gas. }
$$

Outcomes are illustrated in Figure 3, with trajectories of oil and gas extraction for the three sets of resource estimates implied by the resource estimates of NPD (2010). The startup of the oil field is followed by a brief ramp-up period, before the extraction rate peaks at a level which in practice is defined by the extraction capacity of the project. Gradual decline sets in after five years of extraction, with an average annual decline rate of 6 per cent during the remaining 35 -year lifetime of the field (Höök and Aleklett, 2008; Mauritzen, 2017; IEA, 2013).

Extraction paths in accordance with NPD's (2010) resource estimates are illustrated in the left-hand panel of Figure 3. The Reference scenario assumes that the investment decision for the gas field is taken seven years after exploration is initiated, with a building period of four years. The rate of gas extraction is closely linked to installed capacity, and depend less on reservoir pressure. Accordingly, projected extraction of gas resources show a far less dynamic pattern than for the oil field. Dotted lines illustrate the implied trajectories of extraction for the Low (P95) and High (P05) resource estimates from NPD, respectively (cf Figure 2).

The Reference scenario assumes that capacity is installed to meet the requirement implied by peak production in Figure 3. As noted by one of the referees, oil companies in the real world may decide on a lower extraction capacity. For illustration, the stippled lines of Figure 3 ("Oil restrained"/"Gas restrained") represent extraction paths when extraction capacity is limited to 80 per cent of the peak production level. ${ }^{5}$ A field development project that meets the full peak production

5. An opposite alternative is to abstract from the ramp-up phase entirely, assume that peak production is in year 1, and that decline sets in from year two. The log-normal pattern of the Reference scenario may be seen as a compromise of the two. 
Figure 3: Lofoten: Extraction profiles, exploration and development spending

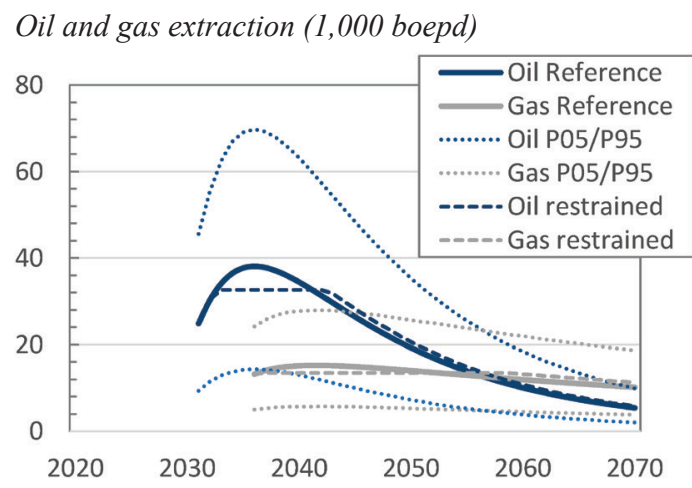

Exploration and development spending (NOK bn)

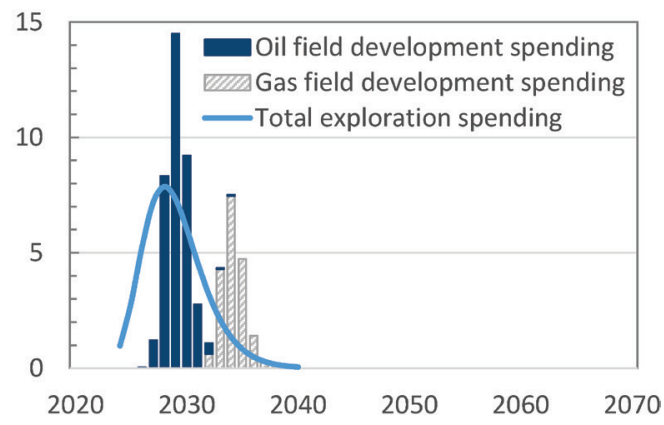

potential of the reservoir will enable maximum front-loading of extraction. However, this benefit comes at a higher cost of development.

In their decision on extraction capacity, oil companies therefore face a trade-off between direct development costs on the one hand and the time value of extracted volumes on the other. With the model and assumptions of the present study, these effects cancel each other out, implying that restraints on extraction capacity only have a very marginal impact on net present values, in particular for the share accruing to the government. I therefore proceed with the stylized extraction profiles in accordance with Equation (3), as represented by the solid lines in the left-hand panel of Figure 3.

\subsection{Cost of exploration, development and production}

Total exploration expenditures for the Reference scenario are illustrated in the right-hand panel of Figure 3. These trajectories are driven by an assumption for unit cost of discoveries. Attribution to oil and gas discoveries is in turn determined by the composition of total resource estimates $\left(Q_{i}=\beta_{i} Q, i=o i l\right.$, gas $)$. Letting $e$ denote average unit cost of discovery, total cost of exploration $\left(E_{i}\right)$ is given by: ${ }^{6}$

$$
E_{i}=e \beta_{i} Q+\theta_{i}^{e} p, i=o i l, g a s,
$$

where $\beta_{i}(i=$ oil, gas $)$ represents the share of oil and gas in total resources, and $\theta_{i}^{e} p$ is an oil price term that captures inflationary feedback effects from oil price shocks on the cost of exploration (e.g., via higher rig rates, service costs, and salaries). For our purpose $p$ is defined as a percentage deviation in the oil price $(P)$ from the oil price level assumed in the Reference scenario $\left(P^{R} ; p=\frac{P-P^{R}}{P^{R}}\right)$, implying that its impact will apply only for sensitivity calculations and alternative scenario excercises. Still, $\theta_{i}^{e}$ can be seen as a semi-elasticity of exploration cost with respect to the oil price, which

6. The geology on the NCS does not allow for very distinct sorting and ranking of exploration prospects according to resource type. Underground structures are mapped and evaluated prior to drilling, but oil companies can never know what type of discovery they will make. Part of the standard pattern of discoveries is also that the oil companies discover fields with both oil and gas resources. In these cases, the oil is extracted first, due to concerns for reservoir pressure, recovery rates, and value maximization. Towards the end of the field life, the gas resources are then let out through gradual pressure relief ('blow-off'), which in turn will bring oil production to a halt. See Mohn (2008) for details. 
will be calibrated based on previous econometric research (e.g., Toews and Naumov, 2015; Skjerpen et al., 2018).

The Reference scenario reflects the composition of resources as estimated and reported by the NPD (2010; cf. Figure 1), implying 64 per cent oil and 36 per cent natural gas. Drawing on Deutsche Bank (2013) and UBS Warburg (2014), the unit finding cost (e) is set at $40 \mathrm{NOK} / \mathrm{boe}$ ( $5 \mathrm{USD} /$ boe) both for oil and natural gas in the Reference scenario, which is also largely in line with historical company data and regional industry data. Expected resources at 1.3 bn boe in the Lofoten region would therefore require NOK 52 bn (USD 6.5 bn) in total exploration expenditures (at 2018 prices), an estimate which is reasonably consistent with previous studies by the NPD (2012a). ${ }^{7}$

Historical data reveals that around 80 per cent of total exploration expenditures on the Norwegian Continental Shelf are related to exploration drilling, with the remaining 20 per cent split between general studies, prospect evaluation, and administration activities. With a drilling cost of NOK 500 M (USD $62.5 \mathrm{M}$ ) per well, a total of 80 exploration wells would be required to discover the resources under the Reference scenario. The actual evolution of exploration efforts and results over time will depend on learning-by-doing and technology development, available exploration prospects, cash availability (i.e., oil price), and risk appetite among the oil companies. ${ }^{8}$

Total cost of field development is based on calibrated development cost per unit of production capacity $\left(d_{i}, i=o i l\right.$, gas $)$, with the capacity requirement being determined by the peaks of the extraction profiles $\left(\bar{q}_{i}=\max \left(q_{t}^{i}\right), i=\right.$ oil, gas, $\left.t=2021, \ldots, 2070\right)$. Thus, total cost of development $\left(D_{i}, i=o i l\right.$, gas $)$ is given by:

$$
D_{i}=d_{i} \cdot \bar{q}_{i}+\theta_{i}^{d} p, i=\text { oil, gas, }
$$

where, again, an oil price term $\left(\theta_{i}^{d} p\right)$ is introduced to capture oil price effects on development costs, in accordance with the above discussion of exploration costs. Based on recent data for comparable oil field developments on the NCS, an estimate of NOK 350,000 (USD 43,750) per boepd of daily production capacity is applied for the sample Lofoten oil field. Gas fields typically require more investment for processing facilities and transport infrastructure, leading to an assumption of NOK 450,000 (USD 56,250) per boepd of daily production capacity for the sample Lofoten gas field, which also matches fairly weall comparable previous gas field projects on the NCS (NPD, 2012a).

As illustrated in the right-hand panel of Figure 3, exploration expenses start accruing in 2024, with a 6-year ramp-up to a peak level just below NOK 8 bn in 2028 (USD 1 bn), when annual exploration activity also peaks at 12 exploration wells. Decline then sets in, and exploration activities are phased by 2035. Field development expenditures are illustrated in the right-hand panel of Figure 3, with separate spending profiles for oil and gas field developments. With available results from seismic studies and relatively good prior knowledge of neighbouring areas, one or more early discoveries are assumed to trigger field development, with final investment decision(s) in 2026, and

7. This unit cost estimate of exploration reflects historical data for all exploration activities, which include a variety of areas, drilling depths, and geological formations (plays). In particular, average historical exploration cost will include not only wildcat drilling in virgin areas, but also low-risk "step-out" drilling from producing fields. Discovery rates are typically significantly higher for the latter type, whereas expected discovery sizes are higher for the former. Both total and average drilling volumes are also smaller for low-risk exploration. Consequently, the average unit cost of discoveries need not be very different across these exploration plays, although the risk profiles are often quite divergent (Mohn, 2008).

8. Technically speaking, the cumulation of discovered oil and gas resources is determined by the product of exploration efforts, discovery rates, and discovery size (Fisher, 1964). These three components will in turn depend on explanatory factors relating to geology, technology, economics, and policies. See Mohn (2008) for an econometric study of exploration activities and success on the Norwegian Continental Shelf. 
Figure 4: Lofoten: Cost of oil and gas field operation

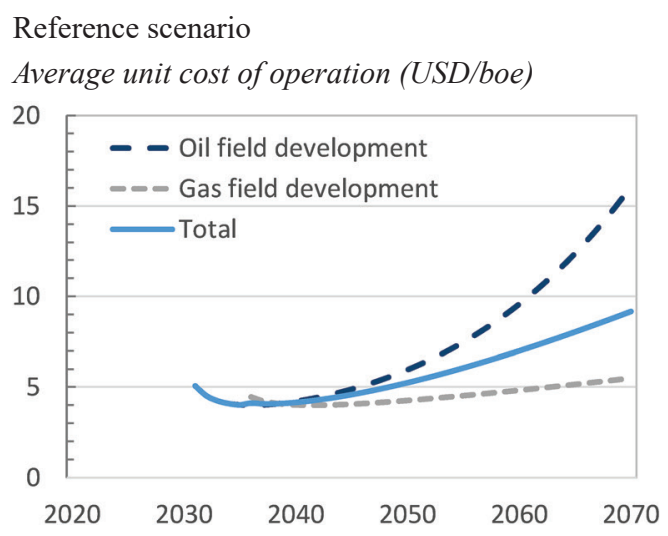

Total costs of field operation (NOK bn 2017 prices)

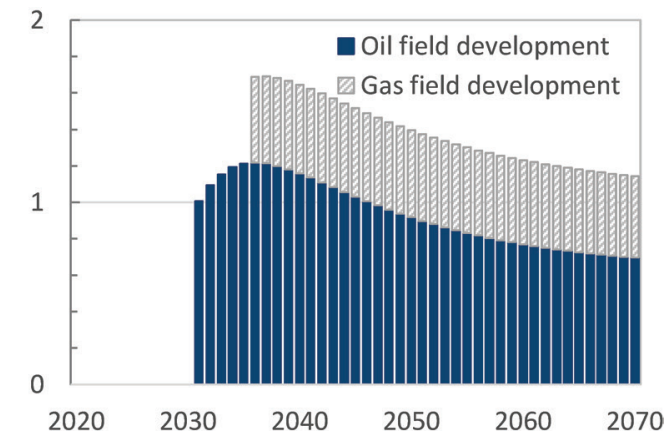

a development lag of five years, which requires that the development projects are not not too large and complex. As exploration and development spending is linked to resource-specific unit costs of discovery and extraction capacity, projections of exploration and development will depend on the size and composition of total resource estimates.

Unit costs of extraction $\left(c_{i t}\right)$ are partly determined by installed capacity $\left(\bar{q}^{i}=\max \left(q_{t}^{i}\right)\right)$, partly by actual production activity $\left(q_{i t}\right)$, and partly by oil price shocks $(p)$, yielding for total costs of operation $\left(C_{i t}\right)$ :

$$
C_{i t}=\gamma^{i} \cdot \bar{q}_{i}+\delta^{i} q_{i t}+\theta_{i}^{c} p, i=o i l, g a s,
$$

Whereas marginal cost of operation is given by the coefficient on the actual rate of extraction $\left(\delta^{i}\right)$, average unit cost of the Reference scenario $(p=0)$ are now given by:

$$
\frac{C_{i t}}{q_{i t}}=\frac{\gamma^{i} \cdot \bar{q}_{i}}{q_{i t}}+\delta^{i}, i=\text { oil }, \text { gas } .
$$

From Equations (6) and (7) we see that the unit cost of peak production $\left(q_{i t}=\bar{q}_{i}\right)$ is given by the sum of the two coefficients $\left(\gamma^{i}+\delta^{i}\right)$. With a fixed-cost element of capacity, Equation (6) also implies that the unit cost of extraction will fall in the initial ramp-up phase. Moreover, this choice of functional form is also supportive of the regular pattern of increasing unit costs towards the end of the field life. As oil production is more dependent on reservoir pressure than natural gas, it will also exhibit more variation over the field life (cf. Figure 3). Specifically, a pattern is reproduced whereby the average unit cost of production are more stable for gas fields than for oil fields. Based on historical data and previous studies of field operation on the NCS and elsewhere in the world (e.g., Deutsche Bank, 2013; Union Bank of Switzerland, 2014), I set [ $\left.\gamma^{i}, \delta^{i}\right]$ at $[2.0,2.0]$ in NOK terms for the oil field and [3.0, 1.0 ] for the gas field. Implied trajectories for average unit costs in real USD terms, and total operational costs in real NOK terms are illustrated in Figure 4.

\subsection{Discounted cash flows}

What remains to compute future cash flows is assumptions for oil and gas prices. For the Reference scenario, the oil price is assumed to remain constant at $480 \mathrm{NOK} / \mathrm{bbl}$ (60 USD/bbl) in real terms, which is largely in line with futures contracts of the current oil market. The average sales 


\section{Figure 5: Lofoten: Projected cash flows from from oil and gas extraction}

Reference scenario (NOK bn, 2017 prices)

Cash flows by resource type

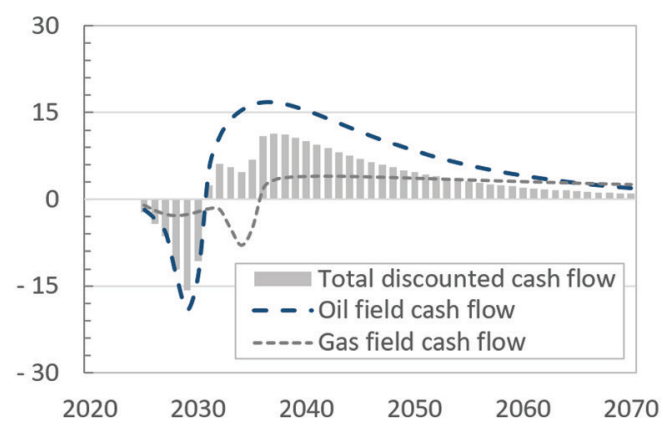

Government and oil companies

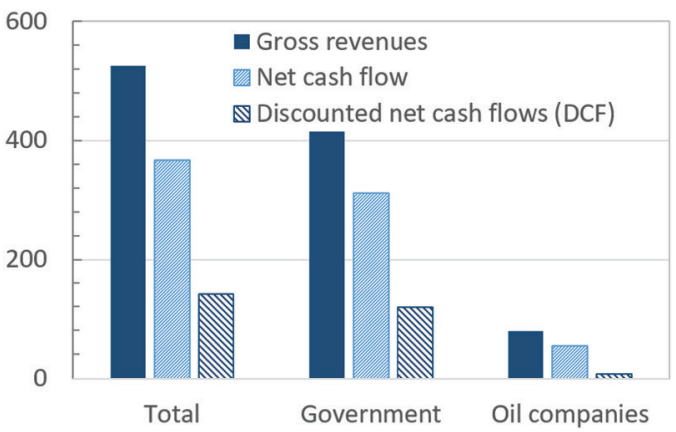

price for natural gas is assumed at $2 \mathrm{NOK} / \mathrm{scm}(\sim 6.60 \mathrm{USD} / \mathrm{MMBtu})$ in real terms, which is also roughly where natural gas is trading in the current European gas market.

Cash flows in real terms are illustrated in the left-hand panel of Figure 5. Negative cash flows in the early phase of operation are due to large expenditures for exploration and field development, before the total sum turns into positive terrain as soon investment levels off, and the oil field starts producing from 2031. The discount rate of the Reference scenario is set at three per cent in real terms, which reflects the required rate of return on government investment as also implied by the expected rate of return for the Norwegian Government Pension Fund. All cash flows are discounted back to 2018. With 50 years of discounting, the contribution to the total net present value from the cash flow in 2070 is 0.7 per cent, indicating that an extension of the field life would have a very limited impact in net present value terms, even at low discount rates.

The right-hand panel of Figure 5 illustrates the total sum of key figures from various stages of the valuation process. Assuming stability in the tax regime and government direct investment according to historical patterns imply that government take will represent 85 per cent of the sum of annual cash flows, leaving NOK 55 bn (USD 7 bn) for the oil companies. ${ }^{9}$ Discounting at 3 per cent gives a net present value at NOK 120 bn (USD 15 bn) for the government. Cash flows accruing to the oil companies are discounted with 7 per cent for oil, whereas cash flows from gas fields are discounted by 5 per cent in real terms. ${ }^{10}$ This leaves a net present value of NOK 7 bn (USD 0.9 bn) for the oil companies, of which 86 per cent stems from the oil field development.

9. 'Government take' represents the share of the annual cash flow expected to accrue to the government, with tax revenues, net cash flows from direct investment, and dividends from Statoil (67 per cent government ownership) as the most important components. Again, assumptions for petroleum tax and government direct investment are in line with current regulation and government behaviour, also reflected in previous studies by the Norwegian Petroleum Directorate (2012b, 2014).

10. Gas fields are normally characterized by longer field lifes and less volatile revenues than typical oil fields, and oil companies' discount rate for gas fields is therefore set two percentage points lower than for oil fields. With 64 per cent oil, 36 per cent gas, and two per cent inflation, this leaves a weighted discount rate for oil companies at 8.3 per cent. For comparision, the capital cost of US E\&P companies is estimated at 8 per cent, whereas the corresponding estimate for European oil companies is 8 per cent, according to Aswath Damodaran (Stern School of Business, New York University), who maintains a data set for financial market data at his web site (http://pages.stern.nyu.edu/ adamodar/). 
Figure 6: Lofoten: NPV sensivities to resource volumes, oil and gas prices
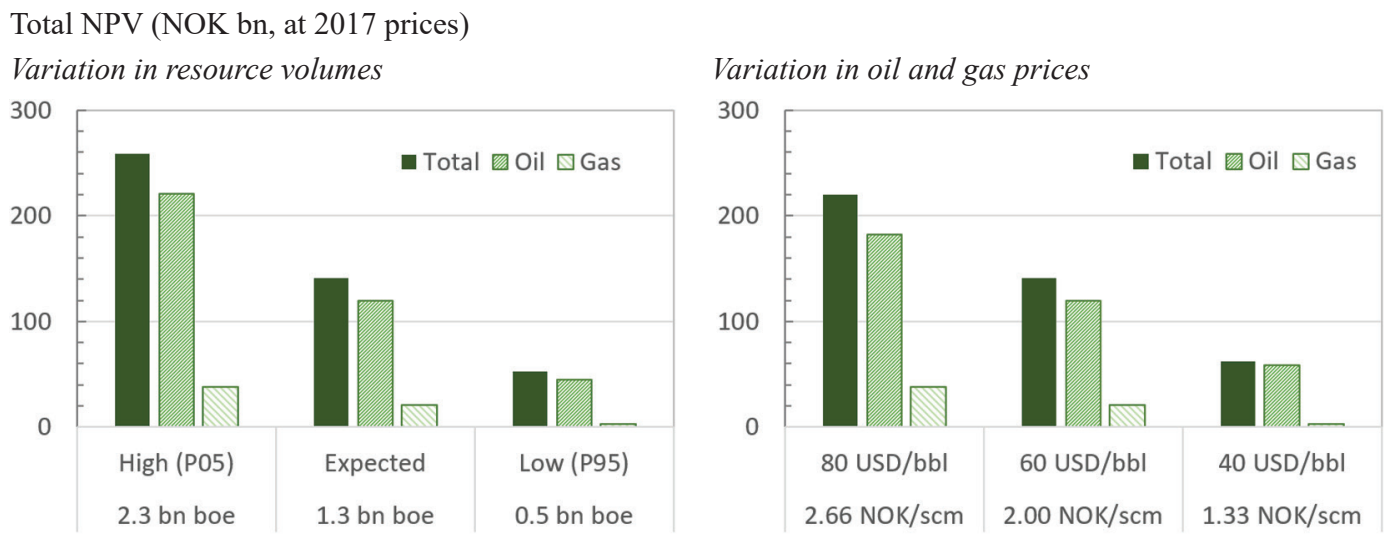

\subsection{Sensitivity analysis and scenarios}

Uncertainty and risk in oil and gas projects span a range of value drivers, and no ex ante risk analysis can possibly address them all. However, the risks involved in oil and gas exploration and extraction may be sorted in four broad groups: Underground risk, technological risk, risks related to markets and prices, and risks related to politics and policies. Any assessment of uncertainty and risk should therefore ensure representation of these broader groups of risk factors. In the following I will therefore examine the role of resource size (underground risk), cost (technology), oil and gas prices (markets and prices), and discount rates and progress delay (policies and politics).

Figure 6 illustrates sensitivities in total net present value to different assumptions for oil and gas resources and respective prices. ${ }^{11}$ As seen from the left-hand panel, doubling the size of resource volumes will cause a corresponding increase in total NPV, indicating a resource elasticity of NPV with respect to resource volumes around unity. The right-hand panel illustrates the response in total NPV to a parallel shift in oil and gas prices of $+/-33$ per cent. Note that the percentage change in NPV is larger than the percentage change in oil and gas prices, suggesting that the price elasticity of NPV is higher than one. An explanation for the difference in sensitivities is that changes in resource volumes have an impact on costs of exploration, development, and operation, whereas changes in prices do not. However, both historical experience and previous research provide evidence that supplier prices and costs may indeed respond to cyclical variables, including the oil price (e.g., Toews and Naumov, 2015). These effects escape our modelling approach, and as we will see they imply that the price sensitivities of Figure 6 could be overestimated. ${ }^{12}$

Uncertainty in the real world can not be isolated to marginal analysis of individual value drivers. Partial sensitivities will therefore only offer a limited and stylised representation of the distribution of uncertainty around the NPV. A more complete investigation should ideally involve the covariance matrix of all value drivers, as these are unlikely to be statistically independent. One response is to design scenarios for the NPV based on specific combinations of assumptions for key

11. In practice, expectations for extracted oil and gas volumes (i.e., reserve estimates) will hardly be independent of oil and gas prices. High oil and gas prices will normally be associated with higher levels of exploration activity and larger discoveries (Mohn, 2008), more profitable development projects, and more activity to extend field-lives, and increase the recovery rates of producing fields, (Watkins, 2002; Mohn, 2009). The implication is that expected volumes of oil and gas extraction are endogenous to market conditions and policy context.

12. See section 3.3 for additional sensitivity analysis, including also discount rates and general progress delays. 


\section{Figure 7: Lofoten: NPV sensitivities with endogenous reserves and costs}

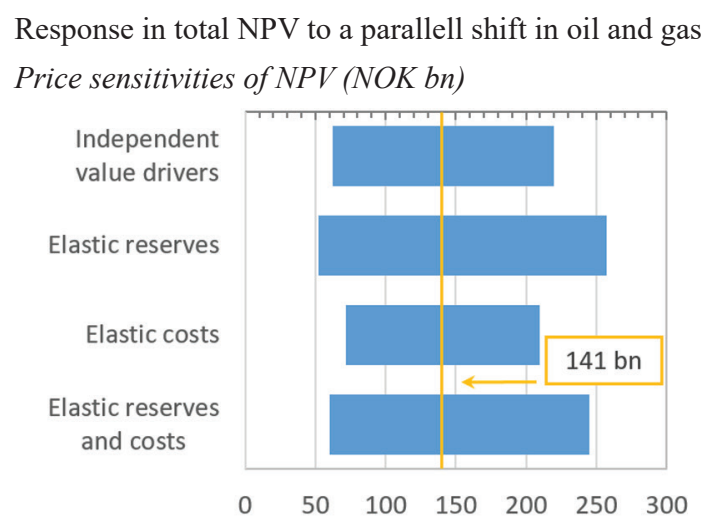

Decomposed change in NPV

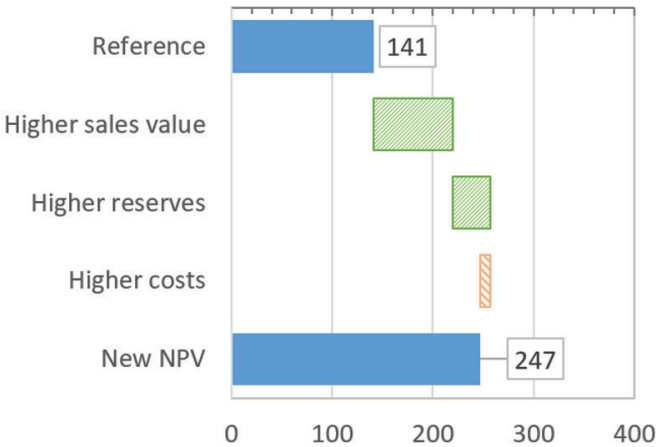

Note: The point of departure is the impact on NPV under the Reference scenario from a parallel (and permanent) shift in oil and gas prices of $+/-33$ per cent. The left-hand panel illustrates the price sensitivity of total NPV under various assumptions for correlation between value drivers. The right-hand panel illustrates how the total impact on NPV from a 33 per cent price increase can be de-composed into a pure value effect ('Higher sales value'), an effect via higher resource volumes ('Higher resource volumes'), and an offsetting effect via higher costs of exploration, development and operation ('Higher costs').

value drivers like extraction rates, oil and gas prices, and costs. These relationships should also be supported by theory and previous empirical research. As an example, an increase in the oil price would make marginal field projects more attractive and potentially also extend the field life of producing fields. This means that expected volumes of extraction, or oil and gas reserve estimates, are sensitive to oil and gas price changes. At the same time, an increase in the oil price will also improve the availability of cash in the oil companies. Consequently, general oil company spending will usually increase on the back of an oil price boom (Jensen, 1986; Bøhm, 2018), leaving a risk of subsequent wage and cost pressures in the supplier industry. In other words, oil and gas prices may be exogenous to the oil and gas companies' decisions on exploration activity, field development, and cumulated production. However, cost levels are most likely not.

The relevance and potential importance of these mechanisms can be illustrate through appropriate scenario design to investigate how the NPV might respond to changes in oil and gas prices. Obviously, an increase in the oil price will lift the level of revenues for a given level of oil and gas extraction. However, a permanent shift in the oil and gas price level may also have a stimulating effect on both expected and cumulated extraction, due to more drilling activity and discoveries, more field developments, more investment in producing fields, and more investment to extend field-lives. Based on findings in previous research on oil exploration and reserve generation (Farzin, 2001; Mohn, 2008, 2009), the response in total oil and gas reserves to a one per cent increase in product prices is assumed at 0.5 per cent. Drawing on Toews and Naumov (2015), I further assume that a parallel positive shift in oil and gas prices of one per cent will lift all costs of exploration, development, and operation by 0.3 percentage points (i.e., $\theta_{i}^{e}=\theta_{i}^{d}=\theta_{i}^{c}=0.3, i=$ oil, gas).

Results of combined scenarios for oil and gas price sensitivities are illustrated in Figure 7. The left-hand panel depicts the impact on total NPV from a change in oil and gas prices of $+/-33$ per cent under four sets of assumptions for the covariance matrix between oil and gas prices on the one hand, and reserve volumes and costs on the other hand. The first bar ('Independent value drivers') assumes no interaction between oil prices, reserve volumes, and costs. In this case a permanent increase in oil and gas prices of 33 per cent will raise total NPV by NOK 86 bn (USD 10.8 bn). The second bar ('Elastic reserves') involves an assumption that (only) expected cumulated extraction is 
influenced by oil and gas prices, according to the above discussion. We see that this will add to the original oil price sensivitity, due to the positive interaction between prices and expected production. The third bar ('Elastic costs') goes on to illustrate how the price sensitivity of total NPV is influenced if (only) the cost level responds to oil and gas price changes, whereas reserve volumes remain unchanged. We see that the original sensitivity is moderated, as a change in oil and gas prices now will cause a response in the cost level of the same sign, which again will dampen the effect of price changes on total NPV. Finally, the bottom bar illustrates the sensitivity of total NPV to oil and gas price changes when both reserve volumes and costs respond to changes in oil and gas prices. For this latter case, the right-hand panel of Figure 7 illustrates how the impact on total NPV from an increase in oil and gas prices of 33 per cent can be decomposed into the three value drivers.

Results so far illustrate that the difference is large between gross sales value and net present value. ${ }^{13}$ Moreover, the valuation analysis clearly suggest that oil resources are significantly more worth than gas resources, due to higher unit value (price), lower cost of development, and more front-loading of production, which also makes oil field development less sensitive to changes in the cost of capital. The next step is to explore the impact of the valuation study for public finance, and investigate the implications for the Norwegian GPF, for the government budget, and fiscal capacity.

\section{RESOURCE WEALTH AND PUBLIC FINANCE}

\subsection{Theoretical point of departure}

An important result from academic research on research revenue management originates from Hartwick (1977), who called for re-investment of resource rents to sustain their purchasing power across future generations. Combining this so-called Hartwick rule with the well-known Permanent Income Hypothesis (PIH) of consumption theory leads to a conclusion that consumption of resource revenues should correspond to the annuity offered by total resource wealth (van der Ploeg and Venables, 2011, 2012; van den Bremer et al, 2013). These principles have lead economists to a benchmark model of resource revenue management, involving the establishment of a sovereign wealth fund (SWF) to smooth consumption from resource revenues across generations.

A complete derivation of resource revenue management principles under $\mathrm{PIH}$ and $\mathrm{BIH}$ approaches is offered by Harding and van der Ploeg (2013). This exposition is therefore limited to some key insights for the implied behaviour in terms of aggregate saving and spending. For resource-rich countries with an SWF in place, the benchmark model means that resource rents are reinvested in financial markets, and spending is determined simply by the permanent income of total wealth. Focusing on natural resources, and abstracting from other components of national wealth, total wealth is given by the sum of expected unextracted natural resource values $\left(E\left(w_{t}^{p}\right)\right)$ and the cumulated value of reinvested resource revenues, i.e. the market value of the SWF $\left(w_{t}^{f}\right)$. Denoting expected annual real return by $r$, spending $\left(g_{t}\right)$ from petroleum-related wealth at any point in the extraction cycle can now be represented by:

$$
g_{t}=r \cdot\left(E\left(w_{t}^{p}\right)+w_{t}^{f}\right)
$$

13. It is perhaps not very surprising Norwegian oil industry interests opt for the largest figures for net gross sales revenues as indicators of activity, value-added, and additions to government budget capacity in their lobbying activity for opening of the Lofoten area. However, it is more of a puzzle that the Norwegian Government tends to play down the role of costs and discounting in their impact assessments for exploration activities in new areas (e.g., Norwegian Petroleum Directorate, 2012b; Ministry of Petroleum and Energy, 2012, 2013). 
where the evolution over time in the composition of total wealth $\left(w_{t}^{p}+w_{t}^{f}\right)$ is determined by the pace of extraction and/or the cash flow from the resource sector. Equation (8) implies a separation of accrual and expenditure of resource revenues. Policies based on forward-looking consumer behaviour will therefore have a stabilising effect on the non-resource economy in the short to medium term. The reason is that an expenditure rule based on Equation (8) will ensure that the non-resource economy is sheltered against temporary resource-related shocks. At the same time, compliance with the Hartwick rule will maintain the real value of resource-related revenues over time, and safeguard their purchasing power for future generations.

Equation (8) implies that once a resource discovery is made, a resource-rich country with access to international capital markets is advised to borrow and consume according to the expected permanent income from total resource-related wealth. Over time, resource revenues are then used for debt-service, and later to build a portfolio of real and/or financial assets that can sustain consumption over the longer term. Over time, this will also facilitate a gradual diversification of national wealth, as resource wealth is converted from natural resources to a broader portfolio of securities and real assets.

Deviations from the benchmark model of Equation (8) may be justified by constraints on capital access or domestic absorption (van der Ploeg and Venables, 2012), by rent-seeking activities (Torvik, 2018), and by prudence and precautionary saving (van der Ploeg, 2011). Substantial uncertainty pertains to the value of below-ground oil and gas resources, relating to geology, technology, prices, and policies. A more prudent variant than the PIH approach is given by the so-called BirdIn-Hand $(\mathrm{BIH})$ rule, which implies that the below-ground component of total resource wealth is excluded from the the spending rule. Note first that total capital on the SWF $\left(w_{t}^{f}\right)$ evolves according to:

$$
w_{t}^{f}=(1+r) \cdot w_{t-1}^{f}+h_{t-1}-g_{t-1},
$$

where $h_{t}$ represents the annual cash flow to the government flow from resource-related activities. A fiscal policy rule guided by the Bird-In-Hand approach will now involve a spending target $\left(g_{t}^{*}\right)$ for resource wealth in accordance with the real return of the SWF:

$$
g_{t}^{*}=r \cdot w_{t}^{f}
$$

We see that under the BIH rule, consumption of resource-related revenues is no longer constant, and that the growth over time is linked directly to the cumulation of cash flows from resource extraction on the SWF. The BIH rule deviates from standard first-order conditions of forward-looking optimization, and welfare gains can be obtained by an adjustment in spending behaviour towards the rule implied by the PIH approach of Equation (8) (van den Bremer et al, 2013). Note also that spending in accordance with Equation (10) means that the change in the market value of the SWF is largely determined by annual net revenues from the resource sector $\left(h_{t}\right)$.

Based on this framework, we now move on to explore the implications of oil and gas exploration in the Lofoten region for government financial wealth and fiscal capacity in Norway. But for a minimum of specific background and context, we first take a brief look at some overall developments in resource management policies in Norway.

\subsection{Resource revenue management in Norway}

The Norwegian model of resource management is generally perceived as successful, in particular when compared to resource-rich countries elsewhere in the world. The loss of cost com- 
Figure 8: Key figures in Norway's resource revenue management

Annual extraction and capital on the Government Pension Fund (GPF)

Oil and gas production (M boepd) GPF:

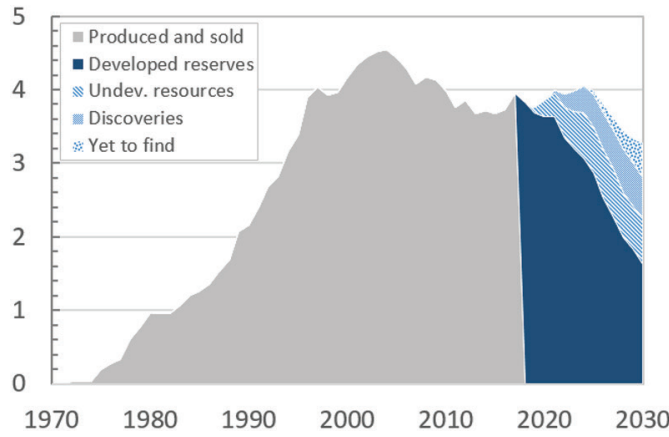

Total capital (NOK bn, nominal)

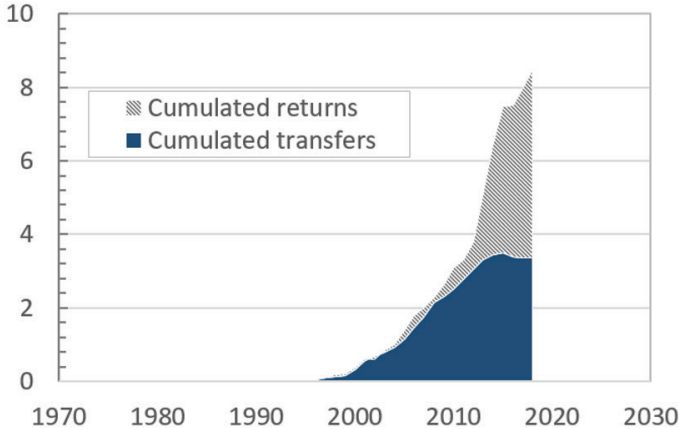

Sources: Norwegian Petroleum Directorate and Norges Bank Investment Management.

petitiveness has been contained, growth rates of non-oil GDP have been maintained, and Norway has accumulated large excess revenues from oil and gas on the Government Pension Fund, with current total capital of NOK 8,400 bn (USD 1,050 bn). The Norwegian model of resource revenue management is therefore regularly argued to hold valuable lessons for resource-rich countries elsewhere in the world (Larsen, 2006; Holden, 2013; Mohn, 2016). Macroeconomic policies for resource revenue management in Norway are typically designed to combine concerns for business cycle stabilisation with distributional aspects across space, income groups, and time.

Key figures for petroleum activity and government financial wealth are illustrated in Figure 8. Direct investment by the government has been significant since the inception of oil and gas activities in the early 1970s, and in line with standard practice of government budgeting, fixed capital investment are expensed directly - without a scheme of gradual depreciation. The implication is that cash-flows to the Government from the oil and gas sector were suppressed by high capital expenditures for two decades, before they shot up in the late 1990s. This surge in cash flows called for a predictable and transparent mechanism to guide the absorption of oil and gas revenues into the Norwegian economy.

Adjusted guidelines for monetary and fiscal policies were adopted in 2001. As illustrated by Figure 9, the policy framework of Norway's resource revenue management now implies that the net cash flow from oil and gas activities goes directly to the GPF, where investment returns will add to the total revenues of the fund. In the annual budget discussions, parliament will then then decide on an annual withdrawing from the GPF to finance the non-oil government budget deficit. The 2001 model of fiscal policy also introduced a guideline for long-term absorption of oil and gas revenues into the economy. Specifically, a new fiscal policy rule rule implied that over time, annual withdrawing from the GPF to finance non-oil budget deficits should be in line with the expected annual return from the fund, estimated at four per cent at the time. In 2016, expectations for the long-term return was revised down to three per cent, and so was therefore also the constraint on annual spending from the GPF. ${ }^{14}$

14. Note that the Norwegian model of resource revenue management represents a more cautious and conservative path of consumption than implied by the permanent-income hypothesis (PIH), which would suggest that expenditure and consumption should be based on the permanent income from total wealth, and not limited to accumulated financial wealth. Inclusion of the value of oil and gas resources in the ground to the relevant wealth concept would produce a higher rate of government 
Figure 9: The Norwegian oil fund mechanism and the fiscal policy rule

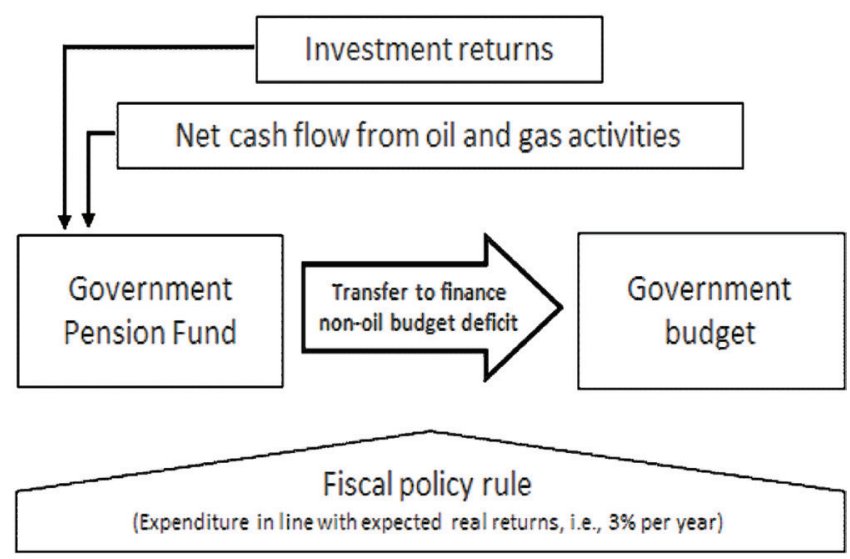

Sources: Norwegian Ministry of Finance and Norges Bank.

Under the Norwegian policy framework, windfall revenues are not readily available for direct expenditure by politicians. Rather, the oil fund mechanism and the fiscal policy rule imply a commitment by Parliament to cut the «umbilical cord» to resource-related revenues. What is left is the indirect effect via the fiscal policy rule. Consequently, the impact on annual fiscal capacity from a permanent positive shock to resource revenues is limited to three per cent of its cumulated value. This mechanism will also imply a dampening of the negative oil-related shocks, as the response in annual spending again is limited to three per cent of the impact on total wealth. This is the policy framework within which the impact of an opening of the Lofoten region now will be assessed.

\subsection{Permanent Income Approach: Long-term fiscal impact of Lofoten exploration}

Our point of departure is to assess the long-term impact of Lofoten oil and gas activities for the GPF and annual fiscal capacity, before we have a closer look at the dynamics implied by the Norwegian 'Bird-In-Hand' approach to resource revenue management. Under the PIH approach, permanent resource-related shocks will have the same effect on public finance as corresponding shocks to the market value of the GPF. The fiscal impact of large discoveries, permanent oil price shocks, or new exploration activity will therefore correspond to similar-sized deposits on the GPF. This is how the NPV from Lofoten oil and gas activities will be framed.

Key results are illustrated in Table 1 . We see that the Reference scenario provides a net present value of NOK 120 bn (USD 15 bn) for the Government. This corresponds to a 1.4 per cent addition to the current value of the Government Pension Fund. Under the fiscal policy rule, a permanent increase in fund value of NOK 120 bn would allow the government to raise annual fiscal spending (or reduce taxes) by NOK 3.6 bn (USD $450 \mathrm{M}$ ), or 0.3 per cent. With a population of 5.285 million, the net present value of Lofoten oil and gas would make up NOK 22,820 (USD 2,847) per capita, on top of the per capita wealth of NOK 1.6 M (USD 200,000) already installed on the GPF. A constant rate of population growth at 0.7 per cent per annum would imply an addition from Lofoten oil and gas activities to annual fiscal capacity of NOK 521 (USD 65) per capita. In other words, 
Table 1: Lofoten: Impact on fiscal policy capacity

Effects on government financial wealth (GPF), annuities and sensitivities

\begin{tabular}{|c|c|c|c|c|c|}
\hline \multirow[t]{2}{*}{ (2) } & \multicolumn{3}{|c|}{ National figures } & \multicolumn{2}{|c|}{ Per capita figures } \\
\hline & $\begin{array}{c}N P V \text { for } G P F \\
(N O K b n)\end{array}$ & $\begin{array}{c}N P V \text { for } G P F \\
\quad(\text { per cent })\end{array}$ & $\begin{array}{c}\text { Ch. in annual } \\
\text { fiscal capacity } \\
\text { (NOK bn) }\end{array}$ & $\begin{array}{r}N P V \text { for } G P F \\
(N O K 1,000)\end{array}$ & $\begin{array}{c}\text { Ch. in annual } \\
\text { fiscal capacity } \\
\text { (NOK) }\end{array}$ \\
\hline Reference & 120 & 1.4 & 3.6 & 22.8 & 521 \\
\hline Sensitivity anc & & & & & \\
\hline $\begin{array}{l}\text { Resource volu } \\
\text { High (P05) } \\
\text { Low (P95) }\end{array}$ & $\begin{array}{c}220 \\
45\end{array}$ & $\begin{array}{l}2.6 \\
0.5\end{array}$ & $\begin{array}{l}6.6 \\
1.4\end{array}$ & $\begin{array}{c}41.8 \\
8.6\end{array}$ & $\begin{array}{l}955 \\
197\end{array}$ \\
\hline $\begin{array}{l}\text { Oil and gas pr } \\
+33 \text { per cent } \\
-33 \text { per cent }\end{array}$ & $\begin{array}{c}187 \\
53\end{array}$ & $\begin{array}{l}2.2 \\
0.6\end{array}$ & $\begin{array}{l}5.6 \\
1.6\end{array}$ & $\begin{array}{l}35.5 \\
10.0\end{array}$ & $\begin{array}{l}813 \\
229\end{array}$ \\
\hline $\begin{array}{l}\text { Cost level } \\
+33 \text { per cent } \\
-33 \text { per cent }\end{array}$ & $\begin{array}{c}90 \\
147\end{array}$ & $\begin{array}{l}1.1 \\
1.7\end{array}$ & $\begin{array}{l}2.7 \\
4.4\end{array}$ & $\begin{array}{l}17.1 \\
27.9\end{array}$ & $\begin{array}{l}391 \\
640\end{array}$ \\
\hline $\begin{array}{l}\text { Discount rate } \\
0 \text { per cent } \\
5 \text { per cent } \\
7 \text { per cent }\end{array}$ & $\begin{array}{c}311 \\
64 \\
34\end{array}$ & $\begin{array}{l}3.7 \\
0.8 \\
0.4\end{array}$ & $\begin{array}{l}9.3 \\
1.9 \\
1.0\end{array}$ & $\begin{array}{c}59.1 \\
12.2 \\
6.4\end{array}$ & $\begin{array}{l}1765 \\
278 \\
190\end{array}$ \\
\hline $\begin{array}{l}\text { Progress delay } \\
1 \text { year } \\
5 \text { years } \\
10 \text { years }\end{array}$ & $\begin{array}{c}116 \\
103 \\
89\end{array}$ & $\begin{array}{l}1.4 \\
1.2 \\
1.1\end{array}$ & $\begin{array}{l}3.5 \\
3.1 \\
2.7\end{array}$ & $\begin{array}{l}22.2 \\
19.6 \\
16.9\end{array}$ & $\begin{array}{l}506 \\
450 \\
388\end{array}$ \\
\hline $\begin{array}{l}\text { Combined scer } \\
\text { "High" } \\
\text { "Low" }\end{array}$ & $\begin{array}{c}\text { f Figure 7) } \\
208 \\
51\end{array}$ & $\begin{array}{l}2.5 \\
0.6\end{array}$ & $\begin{array}{l}6.2 \\
1.5\end{array}$ & $\begin{array}{c}39.6 \\
9.8\end{array}$ & $\begin{array}{l}907 \\
224\end{array}$ \\
\hline
\end{tabular}

Note: The top line of the table provides a summary of fiscal policy key figures of the Reference scenario, before NPV implications of various alternative assumptions are illustrated in the subsequent lines. Net present values for the government are presented in Column 1, whereas Column 2 presents the same value as a percentage ratio to the current market value of the GPF. Column 3 presents the implied increase in annual fiscal capacity, assuming compliance with the fiscal policy rule (3 per cent of GPF value). Per capita NPV measures of Column 4 are based on a 2018 population for all of Norway of 5.285 M, whereas forward-looking estimates for changes in annual fiscal capacity per capita in Column 5 assume an annual population growth of 0.7 per cent, in accordance with the central forecast of Statistics Norway. Sensitivities are presented for partial shifts in key assumptions, along the lines of the above valuation study (volumes of recoverable oil and gas resources, oil and gas prices, cost level, discount rates, and general delays in the progress of opening the Lofoten region for oil and gas exploration). Cost sensitivities illustrate the impact of a parallel shift of all costs relating to exploration, field development, and operation, which are increased/reduced by 33 per cent before discounting. The bottom part of the model reports corresponding figures for two combined scenarios, where positive/negative shifts in oil and gas prices are allowed to influence (cumulated) production, as well as the cost of exploration, development and extraction, in accordance with the exercise of Figure 7.

direct economic effects of oil and gas activities in the Lofoten region would allow a permanent increase in annual government spending (or tax relief) of 65 USD per capita.

The far-right column of Table 1 illustrates the change in annual fiscal capacity in per capita terms, when government budgets are compliant with the fiscal policy rule. For the Reference scenario, it follows that oil industry access to the Lofoten region has the potential of increasing annual fiscal capacity by NOK 521 (USD 65) per capita. This capacity could be exploited for expenditure increase or tax relief. This means that if the Lofoten region is opened for oil and gas exploration, the Government could increase the supply of public services by NOK 521 every year in perpetuity, or they could reduce the tax level a corresponding amount.

Table 1 also report a selection of sensitivity assessments to illustrate some of the uncertainty involved in a valuation process like this. If the High (P05) resource scenario of the Norwegian 
Petroleum Directorate were to materialize, a net present value of NOK 220 (USD 28 bn) would potentially accrue to the Government Pension Fund. The Low (P95) for resource volumes would reduce this amount to NOK 45 (USD $8.5 \mathrm{bn}$ ). As expected, we also see that both net present values and fiscal policy capacity are negatively linked to the cost level. The higher the (wage and) cost level of the oil industry, the less fiscal capacity is left for government. Under the Norwegian resource management regime, this should be seen as a reflection of the implied trade-off between spending by households and companies (costs and wages) on one hand and spending by government on the other.

A discount rate of three per cent is applied for the Reference scenario, in line with current market conditions and return expectations for the Government Pension Fund Global. However, Table 1 also includes sensitivities spanning from zero to seven per cent, which is the discount rate applied by the Norwegian government for direct investment in the oil and gas sector, to account for the highly uncertain market outlook for oil and natural gas. Table 1 also reports sensitivities for delays in development. With the Reference scenario as our point of departure, a delay in all investments by five years will reduce the government share of total NPV by 14 per cent, from NOK 120 bn (USD 15 bn) to NOK 103 bn (USD 13 bn) at a real discount rate of 3 per cent. For comparison, a weighted discount rate of 6.3 per cent (cf. Footnote 9) implies that the NPV impact of a five-year delay is 28 per cent for the oil companies.

Finally, the two bottom lines of Table 1 report the outcomes of parallel shifts in oil and gas prices when we allow for a behavioural response in extraction volumes and cost levels, in accordance with the discussion of section 2.4 above. The "High" scenario lays out implications of a 33 per cent positive shift in oil and gas prices, corresponding directly to the right-hand panel of Figure 7, whereas the "Low" scenario explores the corresponding impact of a 33 per cent negative parallel shift in oil and gas prices.

\subsection{Fiscal policy dynamics: The Bird-In-Hand approach}

So far we have examined potential implications for public finance and fiscal capacity under the assumption that resource revenues are managed according to the Permanent Income Hypothesis of consumer behaviour. However, the Norwegian model takes a more cautious approach, whereby underground resources are virtually neglected as components of total wealth. Balancing concerns for efficiency and uncertainty, Norway has therefore adopted a fiscal spending rule in line with the Bird-In-Hand (BIH) approach. Specifically, the target for the structural budget deficit is contained by expected returns of the GPF, currently estimated at 3 per cent. ${ }^{15}$

Implications of Lofoten oil and gas activities for annual per capital fiscal capacity are illustrated in the left hand panel of Figure 10. The PIH benchmark is consistent with Table 1, computed for an annual rate of population growth of 0.7 per cent, which implies a permanent increase in fiscal capacity of NOK 521 (USD 65) per capita under the Reference scenario. Under the benchmark model, the increase in fiscal capacity is constant over time, and no dynamics are implied. However, the Norwegian approach to resource revenue management is to hold back on any additions in spending until cash flows from oil and gas activities are safely deposited on the GPF. The result is a path for fiscal capacity additions which is very different from the PIH approach, as illustrated by the solid blue line in the left-hand panel of Figure 10.

For the first five years after 2020, before investments are made, a decision to open the Lofoten region for oil and gas activities will have no implications at all, when it comes to direct

15. More background information the Norwegian model resource revenue management is offered by Bjerkholt and Niculescu (2004) and Harding and van der Ploeg (2013). 
Figure 10: Lofoten: Fiscal capacity with a Bird-In-Hand strategy

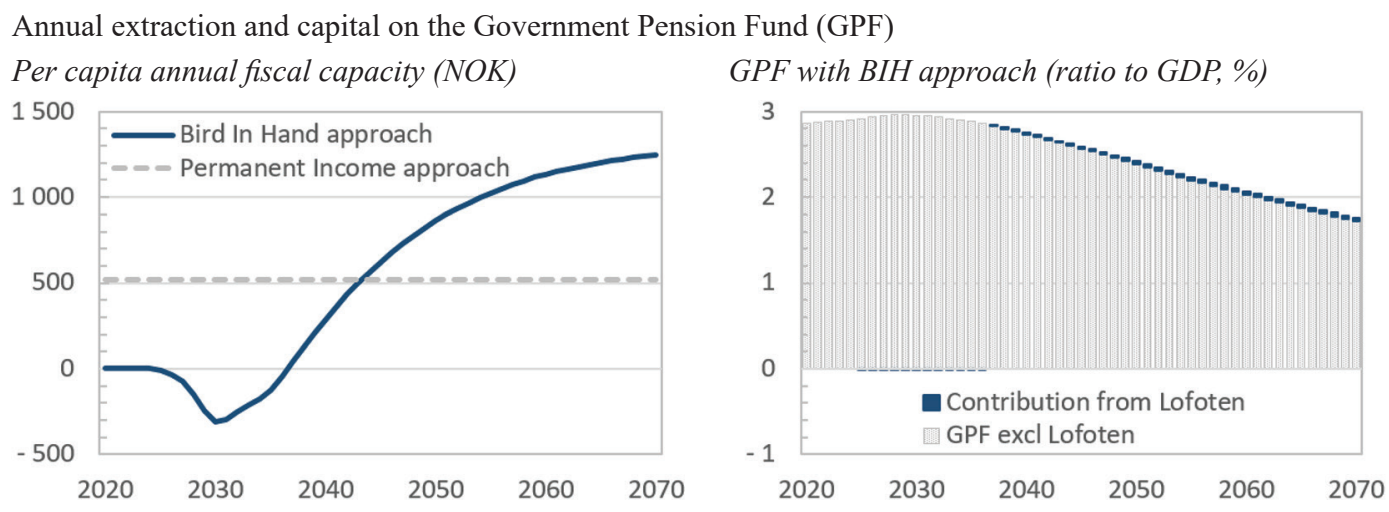

Note: The left-hand panel illustrates contributions from Lofoten oil and gas activities to annual fiscal capacity in per capita terms under the Permanent Income approach and the Bird-in-Hand approach, respectively. Both projections are based on annual population growth of 0.7 per cent, in line with the central population forecast of Statistics Norway. The right-hand panel illustrates the future development of the Government Pension Fund, based on background information from the Ministry of Finance (2017) on long-term GDP growth (trend), expected cash-flows from oil and gas activities, and annual government expenditures in line with the fiscal policy rule ( 3 per cent of fund capital). With aligned assumptions for oil and gas prices, these projections are combined with the contribution from Lofoten oil and gas activities implied by the valuation exercise of this study.

consequences for fiscal policy impact. Note also, that the Norwegian model of resource management implies that oil and gas investment are directly expensed on the Government budget. As the government assumes license shares on the Norwegian Continental Shelf for direct investment, the implication is that the growth of the GPF is actually dampened in periods of high oil and gas investment. Consequently, under the Norwegian Bird-In-Hand approach, Lofoten oil and gas activities will actually put a drag on fiscal capacity during the 10 -year period from 2025-2035. What follows is a period of positive contributions. However, it takes another ten years for the fiscal capacity addition under the BIH approach to catch up with the level implied by the PIH approach. But then, from 2045 and onwards, contributions from Lofoten oil and gas activities grow increasingly higher under the BIH approach than under the PIH approach. As extraction comes to an end in the Lofoten region by 2070 , annual per capita fiscal capacity under the BIH approach is actually 160 per cent above the level of the PIH annuity.

The BIH approach to resource revenue management in Norway was originally adopted as a puppet of prudence. In hindsight, most risk factors have turned out favourably, and the GPF has outgrown everybody's expectations (e.g., Bjerkholt and Niculescu, 2004: Harding and van der Ploeg, 2013). The two approaches to government spending of resource revenues have significantly different implications for the absorption of cash-flows from Lofoten oil and gas activities. However, these differences become less important when compared to the bigger picture.

Today, Norway's GPF stands at NOK 8,400 bn (USD 1,050 bn). As cash flows from oil and gas are expected to embark on a long-term decline from the mid 2020s, the Norwegian Government now expects the real value of the GPF to be outpaced by non-oil GDP (cf Figure 12). Measured as a ratio to GDP, the GPF is seen to peak just below 300 per cent in the late 2020s, and by 2070 its value is expected at 175 per cent of GDP. The contribution from Lofoten oil and gas activities is illustrated in the right-hand panel of Figure 12. In line with the previous discussion, marginal negative contributions are expected until the late 2030s. The contribution from Lofoten oil and gas revenues than gradually climbs to a plateau of around 4 per cent of total GPF value from the 2050s 
and onwards. In summary, the contribution from cumulated cash flows of Lofoten oil and gas activities will therefore offer an addition to 2070 fiscal capacity of roughly 0.1 per cent $(0.04 \times 0.03)$ of the 2070 value of GPF.

Whatever the model of resource management, leaving the Lofoten resources in the ground implies a sacrifice of significant economic value. However, the policy decision will have to rely not only on the direct economic effects, but also include indirect and external effects into a total assessment of net economic benefit. This opens for the possibility that the net present value of direct economic effects can be dominated by the net present value of indirect and/or external costs. This study offers an suggestive sssessment of how large these negative effects will have to be to turn the decision.

\subsection{Arctic oil and public finance: A note on other countries}

According to the Norwegian Petroleum Directorate (2012), the Lofoten region represents approximately 1.3 per cent of total oil and gas resources on the NCS, and around 5 per cent of total undiscovered resources. Consequently, Arctic oil and gas resources in Norway is far more than the Lofoten region. Moreover, Arctic petroleum resources are also not limited to Norway, but actually involve a handful of resource-rich countries in the northern hemisphere with territorial interests within the Polar circle.

In principle, the above valuation model and the subsequent application to resource revenue management can be adapted to any country and region. However, an obvious challenge relates to data availability, in particular for resource volumes and cost estimates. Still, for illustration purposes I go on to present some ballpark valuation estimates for Arctic oil and gas resources in other countries based on the same model as for Norway's Lofoten region above. Substantial uncertainty relating to underground conditions, technology, markets, and policies call for caution around all the below conjectures.

The United States Geological Survey (USGS; 2008) offers an assessment of Arctic petroleum resources, with estimates for total oil and gas volumes at 412 bn boe. A breakdown by country is complicated, as both petroleum provinces and implied geological structures stretch across national borders. Allocating petroleum provinces and resource estimates identified by USGS (2008) to the nearest country, Ernst \& Young (2013) presents a breakdown of Arctic oil and gas resources by country, and this forms the basis for the resource estimates presented in Table $2 .{ }^{16}$ According to these figures, just above 50 per cent of total Arctic petroleum resources are held by Russia, 20 per cent by USA, just above 10 per cent each for Norway and Greenland, and around 5 per cent for Canada. Note also that the share of natural oil in total resources is varying significantly between the countries, from 11 per cent in Russia to 56 per cent in Canada.

In addition to the uncertainty around the resource estimates, two elements of the valuation process are particularly hard to predict. The first relates to the cost of exploration, development and extraction in the various oil and gas provinces involved by the USGS resource estimates. These resources can hardly be discovered and developed at the same cost as for the Lofoten region, where the cumulated competence, experience, underground information, supplier industry, and required infrastructure is already in place. The second element of substantial uncertainty relates to the timing of exploration and extraction. The Lofoten exercise assumed that exploration would commence from 2024, and that oil extraction could start seven years later. This can hardly be expected for Arc-

16. This country allocation of Arctic petroleum resources also compares reasonably well to a corresponding allocation of Arctic oil and gas resources by Henderson and Loe (2014). 
Table 2: Arctic oil and gas: Key figures by country

\begin{tabular}{|c|c|c|c|c|c|c|c|c|c|}
\hline & \multicolumn{3}{|c|}{ Resource estimates } & \multicolumn{3}{|c|}{ Government... } & \multicolumn{3}{|c|}{ National figures } \\
\hline & Total & Oil & Gas & ...take & $\begin{array}{l}\text { NPV } \\
\text { "Bold" }\end{array}$ & $\begin{array}{l}N P V \\
\text { "Sober }\end{array}$ & $G D P$ & $\begin{array}{c}\text { Population } \\
\text { level }\end{array}$ & $\begin{array}{l}\text { Pop. } \\
\text { growth }\end{array}$ \\
\hline & \multicolumn{3}{|c|}{ Bn boe } & Per cent & \multicolumn{2}{|c|}{ USD bn } & $U S D b n$ & Million & Per cent \\
\hline Canada & 20.6 & 9.2 & 11.4 & 48 & 114 & 46 & 1800 & 37 & 0.5 \\
\hline Greenland & 45.3 & 14.8 & 30.5 & 38 & 166 & 59 & $\mathrm{Na}$ & 0.06 & -0.3 \\
\hline Norway & 49.4 & 8.5 & 40.9 & 85 & 327 & 86 & 443 & 5 & 0.7 \\
\hline Russia & 214.2 & 23.5 & 190.7 & 70 & 1058 & 224 & 1720 & 144 & -0.3 \\
\hline USA & 82.4 & 34.3 & 48.1 & 60 & 540 & 211 & 20410 & 327 & 0.3 \\
\hline
\end{tabular}

Note: Gas resource estimates include natural gas liquids (NGL). Resource estimates are based on USGS (2008), with country distribution and government take as reported by Ernst and Young (2013). GDP figures are retrieved from the International Monetary Fund (World Economic Outlook, April 2018) and population figures come from the UN population database (2018 estimates). Population growth is computed as the annual average growth rate over the period 2020-2070, based on UN projections.

tic oil and gas resources in general. As argued by Henderson and Loe (2014), the fact that the Arctic is a region of great variety will also play into the outlook for oil and gas development in the region.

To span this uncertainty, I develop two scenarios as a point of departure for valuation and public finance implications. The "Bold" scenario is built on the same assumptions for upstream cost and timing as the Reference scenario for the above Lofoten exercise. The "Sober" scenario assumes that all costs are 100 per cent higher for Arctic oil and gas resources elsewhere in the world than I assumed in the Lofoten exercise, and that exploration, development, and extraction is delayed by an average of 15 years compared to the Lofoten Reference scenario. All other assumptions, in particular for extraction profiles and oil and gas price trajectories, are the same as for the Lofoten Reference scenario.

With assumptions for government take from Ernst and Young (2013), implied net present values for the government are illustrated in the central part of Table 1. The average NPV estimate is highest for Russia (USD 641 bn), but USA is not as far behind as total resource estimates would suggest. The reason is that the share of oil is significantly higher for USA (42 per cent) than for Russia (11 per cent), and the more valuable oil therefore weighs more heavily in US NPV estimates.

So potentially, Arctic oil and gas resources can be converted to financial wealth for all five countries around the North Pole. Possible implications for government budget capacity are illustrated in Figure 11 by intervals for permanent income implied by the NPV estimates of the "Bold" and "Sober" scenarios. ${ }^{17}$ The relative impact in each country will obviously depend on the size of the economy - and the population. We see that the importance of Arctic oil and gas in relative terms is far less both for Canada and USA than for Norway and Russia. For USA this is explained by the size of its economy and its population, wheras for Canada, the relative role of Arctic oil and gas is weighed down by the modesty of its resource base. Norway and Russia, on the other hand, are countries where Arctic oil and gas could make a real difference. In Russia this is mostly due to the proportions of the resource base. For Norway, on the other hand, a more important explanation is the modest size of the economy and the population (cf Table 2). Figure 11 suggests that successful development of oil and gas resources could leave both Norway and Russia with a potential of adding fiscal stimulus to the amount of a full percentage point of GDP every year. This would suggest

17. For Greenland the permanent-income interval can be computed to [USD 59 bn, USD 166 bn]. However, as GDP figures are missing, permanent income as a ratio to GDP could not be computed for Greenland. With a population at 56,000, per capita figures would also go through the roof. Greenland is therefore left out from the rest of this exercise calculations of permanenc income in relative terms. 


\section{Figure 11: Arctic oil and gas wealth: Implied annuities by country}
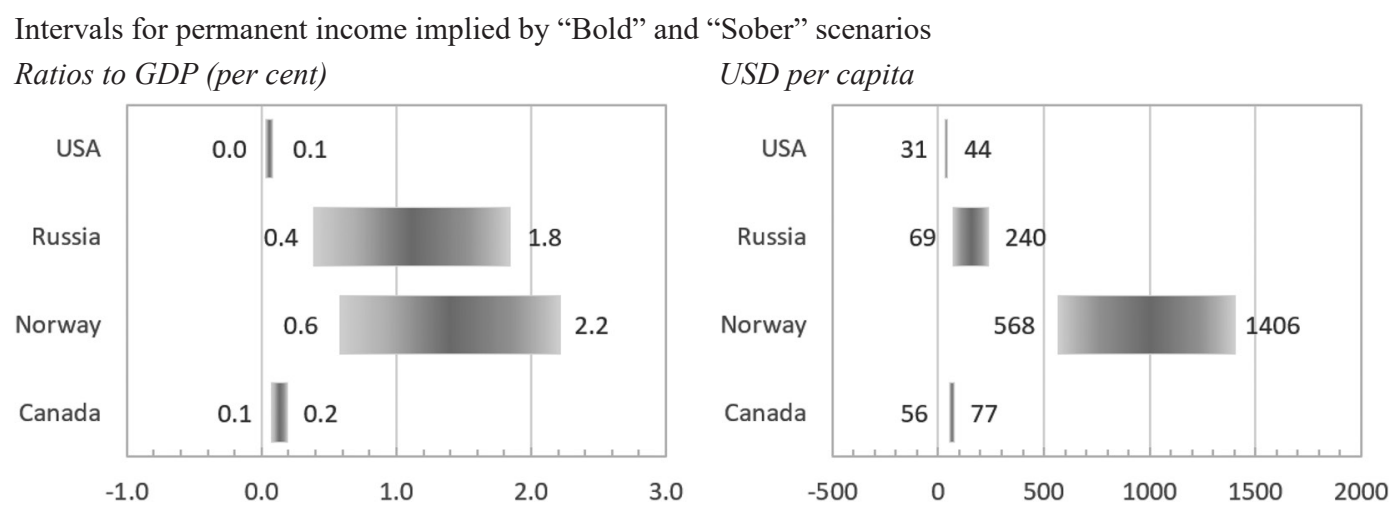

that the national strategic interest in Arctic oil and gas development is also significantly more pronounced for Norway and Russia than for USA and Canada.

Arctic oil and gas resources represents attractive prospects, with potentially significant implications for government budget capacity in resource-rich countries. However, development so far has been sluggish. Resources are largely offshore, in hostile waters, low temperatures, with challenging icing conditions during large parts of the year. Geological uncertainties are substantial, and new technology is required for successful development in large parts of the Arctic. As these resource are located far from their markets, challenges also apply to processing and transport through harsh waters and weather conditions. Finally, policies over the last year have turned in favour of the environment, adding headwinds for those who want to accelerate the development of Arctic oil and gas resources. Both the Lofoten exercise and the above extension therefore suggest that potentially important economic elements could easily escape the framework of a conventional NPV analysis based on direct economic effects. How to incorporate additional aspects ahead of a decision to facilitate development of Arctic oil and gas resources is what we turn to next.

\section{DISCUSSION: INDIRECT AND EXTERNAL EFFECTS}

The perspective of this study is constrained to implications for government financial wealth stemming from direct economic effects of Lofoten oil and gas activities. A full economic assessment will also have to include the net effects from indirect economic effects. From a national perspective, examples include ripple effects on (supplier) industry development and employment in the region and/or crowd-out of traditional industries. Moreover, net benefits from external economic effects will also have to be considered in a full evaluation of the economics of Arctic oil and gas activities. The relevant decision criterion for an invitation of oil and gas activities in the region should be based on the sum of these three valuation elements.

What the Lofoten exercise of this study indicates is that if the sum of net effects related to indirect and external economic effects is negative and exceed the sum of direct economic effects, policy makers should think twice before the Lofoten region is opened for oil and gas exploration. This would mean that the direct contribution to government budget capacity can not compensate for the net impact on welfare from indirect and external economic effects. On the other hand, if the net negative impact of external and indirect effects fall short of the sum of direct effects, opening of new Arctic regions for petroleum activities could be justified. At this point it is also worth noting that the approach of this study does not offer an explicit estimate of the willingness to pay for protection of 
the region in question. It does, however, suggest a threshold that this willingness to pay will have to exceed, to justify for the region to remain out of reach by the oil companies.

Ripple effects from Arctic oil and gas activities can materialize both at the regional and national levels, and in principle they might be positive or negative. Oil and gas exploration is likely to encourage establishment and development of supplier companies in the region. In turn, oil company spending will therefore give rise to local industry activity and employment. As illustrated by this study, the stimulus to activity and employment lies quite far into the future. And in a long-term perspective, it is not straightforward to argue that the alternative to oil-related employment is unemployment. To approach the economic impact of ripple effects, one therefore has to explore net effects on total employment from Arctic oil and gas activities, and also consider net benefits from an adjustment of the regional industry structure. Potential negative contributions may stem from crowd-out, loss of activity and income in fishery and tourism, as well as wage pressures which could undermine the competitiveness of other industries, both for specific oil and gas region and on a national level. The discounted net effect of all indirect effects will therefore have to be added to the corresponding value of direct effects.

The last group of effects involve external benefits and costs, or effects that do not form part of the decision process of any of the companies involved in business development and investment in oil and gas activities in the Lofoten region. These effects are generally expected to be negative, and candidates include costs and risks related to nature, environment, and climate policies. An example of a potential external liability relates to the risk of oil spills, which again will have consequences for birdlife, fish stocks, and recreational qualities of the area. In addition comes the potential physical area conflicts with fishery activities, as well as erosion of quality of the region as a tourist destination, due to platforms on the horizon and land-based processing facilities and infrastructure.

Estimation of external effects is complicated, as the goods subject to valuation often do not have a market, and also no data. Valuation of non-market goods will therefore normally be addressed through specially adapted methodology. Survey-based methods are applied to reveal the willingness to pay for quality of nature, environmental goods, and recreational services. Previous studies provide quantitative indications of the willingness to pay among Norwegian households for full protection against oil spills in the Lofoten region. The design of these studies involve scenarios for oil spills and damage which will occur with 100 per cent likelihood some time over the coming 10 -year period. Navrud et al (2016) estimate welfare losses due to ecosystem service loss from oil spills in Norwegian waters, and find that the willingness to pay for avoidance of oil spills in Lofoten varies between NOK 1300 and NOK 2400 (USD 160-300) per household per year, depending on the severity of the implied damage. A similar study of the willingness to pay for avoidance of acute oil spills in Vestfjorden (Lofoten) by Frøystein and Egeland (2016) concludes that Norwegian household on average are willing to sacrifice NOK 1300-1400 for protection against this type of ecosystem service loss.

Quality loss of ecosystem, tourism and recreational services can also involve willingness to pay outside the national borders (e.g., Loureiro and Loomis, 2012), in particular for regions that are highly regarded as destinations for international tourism, as the case is for the Lofoten region. This is particularly relevant if the damage potential is large, and if environmental values are widely appreciated. It may therefore be relevant to note that Lofoten is on the list of potential nominees for UNESCO's World Heritage List. The region attracts around 350,000 tourists during summer season, 60 per cent of which are non-Norwegians. This position suggests that international willingness to pay should be considered in non-market valuation studies of external effects related to oil and gas activities in Lofoten. 
Finally, emissions of greenhouse gases has a cost to society that also should be reflected in assessments of external effects of Arctic oil and gas activities. Norway's oil and gas extraction is included in the EU Emissions Trading System (ETS) for $\mathrm{CO}_{2}$ quotas and is also subject to a specific Norwegian $\mathrm{CO}_{2}$ tax. The result is a cost of $\mathrm{CO}_{2}$ emissions of around NOK 500 (USD 42) per metric tonne in the Norwegian oil and gas industry. If the cost to society is higher than the cost facing companies, the difference should be included explicitly among the external effects in a full assessment of economic effects. Special concerns for domestic $\mathrm{CO}_{2}$ emissions is a potential source of such deviations.

The same logic may apply if the ETS price of $\mathrm{CO}_{2}$ quotas is not sufficiently high to facilitate a readjustment of the energy system in line with political ambitions to address climate change. A Norwegian expert commision (Hagen et al, 2012) recommends the government to impose a cost of $\mathrm{CO}_{2}$ emissions of NOK 930 (USD 116) per tonne, whereas IEA and IRENA (2017) argue that cost of $\mathrm{CO}_{2}$ emissions will have to increase to USD 190 (NOK 1,520) by 2050 to meet the ambitions of the Paris agreement. These estimates would suggest that the cost to society from $\mathrm{CO}_{2}$ emissions are higher than the actual cost of emissions facing the oil and gas industry, at least if the ambitions of the Paris agreement are to be taken seriously. ${ }^{18}$

So far, the perspective on greenhouse gases has been limited to emissions from extraction activities. However, roughly 90 per cent of Norwegian oil is exported, and virtually no natural gas is consumed in the domestic economy. Consequently, emissions caused by consumption are largely taking place in other countries. A possibility is therefore that the decision of opening the Lofoten area for oil and gas activities may have another set of external effects that extend beyond the Norwegian borders, taking us directly into the discussion on global warming and climate policies. ${ }^{19}$

Research activities in recent years have raised attention on climate policies directed at the supply side of oil and gas markets (e. g., Sinn, 2012; Harstad, 2012; van der Ploeg and Withagen, 2015; Fæhn et al, 2017; Lazarus and van Asselt, 2018). An important reason is that announcements of future climate policies can be seen as announcements of future expropriation (Sinn, 2012). Consequently, oil companies who faced with tightening energy and climate policies in the future may respond through accelerated extraction today, which again will result in lower prices of fossil fuels, higher demand, and higher $\mathrm{CO}_{2}$ emissions. The result is that demand side policies may produce leakage of $\mathrm{CO}_{2}$ emissions not only across space, but also across time. The dynamic behavioral response among oil and gas companies may therefore pervert the intention of well-intended climate policies directed at the demand-side of the market. This "Green Paradox" is associated with lower prices of fossil fuels, higher demand and higher emissions of $\mathrm{CO}_{2}$.

Recent research suggest therefore suggest that that climate policies should not exclusively be directed at the demand side of the energy market, and that the optimal mix of demand-side and supply-side policies could potentially involve regulatory measures directed at exploration, field development, extraction by oil and gas companies. This conclusion is particularly robust in the absence of global coordination of climate policies. With long-term elasticities of oil supply and demand of 0.5, Fæhn et al (2017) find that the carbon leakage of supply-side measures are limited to 2/3, im-

18. With an average of 2.2 persons per household, the estimates of Navrud et al (2016) will correspond to an annual willingness to pay of NOK 600-1100 (USD 75-140) per capita, whereas Frøystein and Egeland (2016) will translate to an annual willingness to pay of around NOK 600 (USD 75) on per capita terms.

19. The average emission intensity of Norwegian oil and gas production is around $50 \mathrm{~kg} \mathrm{CO}_{2}$ per SM $\mathrm{SM}^{3}$ oe This means that extraction activities in Lofoten under the Reference scenario of this study will involve cumulated emissions of roughly 10 million tonnes of $\mathrm{CO}_{2}$. In terms of pricing, the difference between actual cost of emissions and assumptions implied by IEA and IRENA (2017; NOK 1,000-1,500 per tonne) gives rise to a cost of NOK 5-10 bn (USD 600-1,200 M). In addition comes potential costs relating to emissions from demand and consumption, which can be significantly higher (cf Fæhn et al, 2017). 
plying that three barrels of oil cut from Norway's total extraction will result in 1 barrel lower oil consumption at the global level. Fæhn et al therefore goes on to argue that optimal climate policies of oil-producing countries should balance effectiveness and cost of demand-side measures against corresponding properties of demand-side measures. Their conclusion for Norway is that marginal abatement costs are minimized when roughly one third of the emission cuts are taken on the demand side, and the remaining two thirds should be implemented through efforts to dampen oil extraction.

To impose supply-side measures on oil and gas fields that are already discovered or developed, is both costly and controversial in the oil industry. To restrict access to exploration acreage where capital is yet to be sunk, may therefore stand out as a less poisonous policy option if Norway is to implement climate policies on the supply side of the oil market. In that sense, there are potential external effects of oil extraction that could link the policy decision on whether or not to open new regions for Arctic oil exploration to global warming and climate policies.

\section{CONCLUSION}

Arctic oil and gas resources are substantial, but so are the challenges implied by conversion to revenues, financial wealth, and welfare gains. Drawing on Norway's Lofoten region as a case, this study presents a proposal for how to approach the broader economics involved by Arctic oil and gas exploration. Even with a scope that is limited to an assessment of direct economic effects, valuation estimates can provide policy-makers with valuable reference and threshold values to which the net benefits of indirect and external effects can be compared.

For oil companies short on investment opportunities, promise and potential are implied by the access to new Arctic oil and gas provinces for exploration and extraction. The development of Arctic oil and gas activity could also involve large revenues and welfare gains at the national level, in particular for countries where oil and gas play a relatively important part in the economy. As resource revenues are basically a part of national wealth, economic theory clearly suggests that spending from resource-related wealth should be limited to its permanent income. Direct revenues from resource extraction is therefore a poor indicator of spending potential and welfare implications. Still, if resource rents are successfully captured and wisely managed, they could add significantly to the government budget capacity even over the longer term.

For policy-makers of resource-rich countries, on the other hand, a wider range of elements weigh into the decision on whether or not to let the oil industry into Arctic waters. Sound decisionmaking by politicians requires careful socio-economic assessments at arm-length's distance from industry interests. As the market outlook and public sentiment is influenced by global warming and climate policies, national incentives to pursue petroleum resources in the Arctic are also modified by reputation risk at the national level. This also means that the credibility of the oil industry is at stake, because their claim for peaceful coexistence with the interests of fisheries, tourism, and environmental organisations is put to the test.

As illustrated by the valuation case of this study, the relative impact of the resources in question also seems to play into the decision process. My approximate valuation for resource-rich countries in the Polar circle clearly suggests that national interests in Arctic oil and gas developments are potentially much more important for Russia and Norway than for Canada and USA. The country-specific history and tradition of resource management could also influence on the incentives to pursue oil exploration in Arctic offshore regions. And so could the general income level and current welfare level of the country in question. As Norway already is already one of the richest countries in the world, with an oil fund at three times of GDP, a potential addition to the oil fund of 
a few percentage points may not be enough to convince the electorate and politicians to go ahead with oil exploration in all available areas in the Arctic.

Although my modelling approach opens for both reflection and wider application, the methodology of this study leaves ample room for sophistication. The deterministic framework is possibly masking important aspects of risk and uncertainty in the real world, which may not be exhausted by simple sensitivities and scenarios. Actual behavior among oil companies and policymakers is also subject to dynamic optimization of profits and welfare, respectively, which is not explicitly accounted for in my approach. A preferred approach would involve a dynamic optimization framework, accounting for special attributes of objectives and constraints among oil producers and resource-rich governments, at best also with an explicit representation of stochastics. In studies of direct, indirect, and external effects implied by Arctic oil and gas exploration, such a framework could set a fruitful direction for further research.

\section{ACKNOWLEDGMENTS}

I wish to acknowledge helpful comments from Kristoffer Wigestrand Eriksen, Gunnar Eskeland, Torfinn Harding, Finn Kinserdal, Gorm Kipperberg, Ola Kvaløy, Kjetil Lund, and Bård Misund for comments on a previous version of this study. I am also indebted to Knut Einar Rosendahl, participants at the 2018 Bergen Economics of Energy and Environment Research Conference (BEEER; Norwegian School of Economics), four referees, and the journal editor.

\section{REFERENCES}

Abrahamsen, Erik B., Vidar Kristensen, Herman Steen Wiencke, and Ingrid Årstad (2010). Verdien av samfunnsmessige konsekvenser av akutt forurensing. (Valuing societal consequence of acute pollution). Report. Stavanger: Petroleum Safety Authority.

Bjerkholt, Olav and Irene Niculescu (2004). Fiscal rules for economies wih nonrenewable resources: Norway and Venezuela. In Rules-based fiscal policies in emerging markets, edited by George Kopits. London: Palgrave Macmillan. https://doi. org/10.1057/9781137001573_11.

Bøhm, Marit (2018). "Oil and gas investment: Agency problems and managerial bias.” Master thesis. University of Stavanger Business School. Downloaded 29 June, 2018. (https://brage.bibsys.no/xmlui/handle/11250/2457061).

Cappelen, Ådne, Torbjørn Eika, and Joachim Prestmo (2012). Nasjonale sysselsettingsvirkninger av petroleumsaktivitet i det nordøstlige Barentshavet. (National employment effects from petroleum activity in the North East Barents Sea). Report. Oslo: Norwegian Ministry of Petroleum and Energy.

Egeland, Ingrid and Ingrid Nilsen Frøystein (2016). "Willingness to pay for preventing an oil spill in Vestfjorden: The role of use versus non-use values." Master's Thesis. University of Stavanger Business School.

Ernst \& Young (2013). Arctic oil and gas. Report. Downloaded 29 June, 2018. http://www.ourenergypolicy.org/wp-content/ uploads/2013/09/Arctic_oil_and_gas.pdf.

Fæhn, Taran, Cathrine Hagem, Lars Lindholt, Sissel Mæland, and Knut Einar Rosendahl (2017). "Climate policies in a fossil fuel producing country: Demand versus supply side policies.” The Energy Journal 38(1): 77-102.

Farzin, Y.H. (2001). "The impact of oil prices on additions to US proven reserves." Resource and Energy Economics 23: 271-291. https://doi.org/10.1016/S0928-7655(01)00040-9.

Fisher, F.M. (1964). Supply and Costs in The US Oil and Gas Industry: Two Econometric Studies. Baltimore: Johns Hopkins Press.

Fjose, Sveinung, Leo A. Grünfeld, Sissel Ovesen, Lisbeth Iversen, and Christian Mellbye (2012). Lokale og regionale samfunns- og næringsmessige ringvirkninger av petroleumsvirksomhet i uåpnede deler av det nordøstlige Norskehavet. (Local and regional economic effects of petroleum activity in the North East Barents Sea). Report 32/2012. Oslo: Menon

Hagen, Kåre P. (2012). Samfunnsøkonomiske analyser. NOU 2012:16. Norway: Ministry of Finance.

Harding, Torfinn and Frederick van der Ploeg (2013). "Official forecasts and management of oil windfalls." International Tax and Public Finance 20: 827-866. https://doi.org/10.1007/s10797-012-9251-y. 
Harstad, Bård (2012). "Buy coal! A case for supply-side environmental policy.” Journal of Political Economy 120(1): 77115. https://doi.org/10.1086/665405.

Hartwick J.M. (1977) “Intergenerational equity and investing rents from exhaustible resources.” American Economic Review 66: 972-974.

Henderson, James, and Julia Loe (2014). "The prospects and challenges for Arctic oil and gas development." OIES PAPER: WPM 54. Oxford Institute for Energy Studies. https://doi.org/10.26889/9781784670153.

Holden, Steinar (2013). "Avoiding the resource curse. The case Norway." Energy Policy 63: 870-876. https://doi. org/10.1016/j.enpol.2013.09.010.

Höök, Mikael and Kjell Aleklett (2008). “A decline rate study of Norwegian oil production.” Energy Policy 36(11): 42624271. https://doi.org/10.1016/j.enpol.2008.07.039.

IEA (2013). World Energy Outlook. International Energy Agency. Paris.

IEA and IRENA (2017). Perspectives for the Energy Transition: Investment needs for a low-carbon energy system. Report. International Energy Agency and The International Renewable Energy Agency.

Ibenholt, Karin, Henrik Lindhjem, John Magne Skjelvik, Ingeborg Rasmussen, Haakon Vennemo, and Hanne Dybdahl (2010). Samfunnsøkonomisk analyse av eventuell utvidet petroleumsvirksomhet i Barentshavet-Lofoten. (Economic consequences of petroleum activity in the Barents Sea). Report 2010/20. Oslo: Vista Analyse.

Jensen, Michael C. (1986). Agency cost of free cash flow, corporate finance, and takeovers. American Economic Review 76(2): 323-329.

Larsen, Erling Røed (2006). "Escaping the Resource Curse and the Dutch Disease? When and Why Norway Caught up with and Forged ahead of Its Neighbors." American Journal of Economics and Sociology 65(3): 605-640. https://doi. org/10.1111/j.1536-7150.2006.00476.x.

Lazarus, Michael, and Harro van Asselt (2018). "Fossil fuel supply and climate policy: Exploring the road less taken." Climatic Change 150(1-2): 1-13. https://doi.org/10.1007/s10584-018-2266-3.

Loureiro, Maria L., and John B. Loomis (2012). "International public preferences and provision of public goods: Assessment of passive use values in large oil spills.” Environmental and Resource Economics 56: 521-534. https://oi.org/10.1007/ s10640-012-9556-4.

Mauritzen, Johannes (2017). "The effect of oil prices on field production: Evidence from the Norwegian Continental Shelf." Oxford Bulletin of Economics and Statistics 79(1): 124-144. https://doi.org/10.1111/obes.12138.

Milne, Richard (2017). Oil and the battle for Norway's soul. Financial Times, 27 July 2017. Downloaded 29 June 2018. https://www.ft.com/content/c2dad93c-7192-11e7-aca6-c6bd07df1a3c.

Ministry of Climate and Environment (2006). Helhetlig forvaltning av det marine miljø i Barentshavet og havområdene utenfor Lofoten. (Management plan for the marine environment in the Barents Sea and Lofoten; White Paper to Parliament). Meld. St. 8 (2005-2006). Oslo: Ministry of Petroleum and Energy.

Ministry of Finance (2017). Nasjonalbudsjettet 2018 (National Budget 2018). Oslo: Ministry of Finance.

Ministry of Petroleum and Energy (2012). Nye muligheter for Nord-Norge - åpning av Barentshavet sørøst for petroleumsvirksomhet (New opportunities for Northern Norway: Opening the Barents Sea South East for petroleum activity ; White Paper to Parliament). Meld. St. 36 (2012-2013). Oslo: Ministry of Petroleum and Energy.

Ministry of Petroleum and Energy (2012). Kunnskapsinnhenting om virkninger av petroleumsvirksomhet i det nordøstlige Norskehavet. (Survey on the impact of petroleum activity in the Northeast Norwegian Sea). Report. Oslo: Ministry of Petroleum and Energy.

Ministry of Petroleum and Energy (2013). Konsekvensutredning for Barentshavet sørøst (Impact Assessment for Barents Sea South East). Oslo: Ministry of Petroleum and Energy.

Ministry of Petroleum and Energy (2014). Facts 2014. The Norwegian Petroleum Sector, edited by Ingvild Tormodsgard. Oslo: Ministry of Petroleum and Energy.

Mohn, Klaus (2008). "Efforts and Efficiency in Oil Exploration: A Vector Error-Correction Approach." The Energy Journal 30(4): 53-78. https://doi.org/10.5547/ISSN0195-6574-EJ-Vol29-No4-3.

Mohn, Klaus (2009). "Elastic Oil: A primer on the economics of exploration and production.” In Energy, Natural Resource and Environmental Economics, edited by Endre Bjørndal and Mette Bjørndal. London: Springer.

Mohn, Klaus (2016). "Resource revenue management and wealth neutrality in Norway.” Energy Policy 96: 446-457. https:// doi.org/10.1016/j.enpol.2016.06.026.

Navrud, Ståle, Henrik Lindhjem, and Kristin Magnussen (2017). "Valuing marine ecosystem services loss from oil spills for use in cost-benefit analysis of preventive measures." In Handbook on the Economics and Management of Sustainable Oceans, edited by Paulo A. L. D. Nunes, Lisa E. Svensson, and Anil Markandya. Chapter 5, 124-137. Cheltenham (UK): Edward Elgar. https://doi.org/10.4337/9781786430724.00014.

Open Access Article 
Norwegian Citizen Panel (2018). Dette mener nordmenn om oljeutvinning i Lofoten og Vesterålen (These are Norwegians' opinions on oil exploration in Lofoten and Vesterålen). Web article downloaded 29 June 2018 (https://www.uib.no/klimaenergi/114382/dette-mener-nordmenn-om-oljeutvinning-i-lofoten-og-vesterålen).

Norwegian Petroleum Directorate (2010). Petroleumsressurser i havområdene utenfor Lofoten, Vesterålen og Senja. (Petroleum resources in ocean areas off Lofoten, Vesterålen, and Senja). Report. Stavanger: Norwegian Petroleum Directorate.

Norwegian Petroleum Directorate (2012a). Aktivitetsbilder for petroleumsvirksomhet i det nordøstlige Norskehavet. (Activity scenarios for petroleum activity in the Northeast Norwegian Sea). Report. Oslo: Ministry of Petroleum and Energy.

Norwegian Petroleum Directorate (2012b). Inntekter frå petroleumsvirksomhet på nasjonalt nivå. (National revenues from petroleum activity in the Northeast Norwegian Sea). Report. Oslo: Ministry of Petroleum and Energy.

Norwegian Petroleum Directorate (2014). Facts 2014. The Norwegian Petroleum Sector. Edited by Ingvild Tormodsgard. Oslo: Norwegian Ministry of Petroleum and Energy.

Sinn, Hans Werner (2012). The Green Paradox: A supply-side approach to global warming. Boston (MA, USA): MIT Press. https://doi.org/10.7551/mitpress/8734.001.0001.

Skjerpen, Terje, Storrøsten, Halvor B., Rosendahl, Knut E., and Petter Osmundsen (2018). "Modelling and forecasting rig rates on the Norwegian Continental Shelf." Resource and Energy Economics 53, 220-239. https://doi.org/10.1016/j.reseneeco.2018.05.004.

Toews, Gerhard and Alexander Naumov (2015). "The relationship between oil price and costs in the oil and gas industry." The Energy Journal 36(SI1): 237-254.

Torvik, Ragnar (2018). “Should developing countries establish petroleum funds?” The Energy Journal 39(4): 85-101. https:// doi.org/10.5547/01956574.39.4.rtor.

Tvinnereim, Endre, and Elisabeth Ivarsflaten (2016). "Fossil fuels, employment, and support for climate policies." Energy Policy 96: 364-371. https://doi.org/10.1016/j.enpol.2016.05.052.

Union Bank of Switzerland (2014). Global oil and gas analyser. Report. Global Resarch. Equities. 14. September 2014.

United States Geological Survey (2008). The 2008 Circum-Arctic Resource Appraisal. Professional paper 1824.

Venables, Anthony J. (2016). “Using natural resources for development: Why has it proven so difficult?” Journal of Economic Perspectives 30(1): 161-184. https://doi.org/10.1257/jep.30.1.161.

van den Bremer, Ton, Frederick van der Ploeg, and Samuel Wills (2013). "The Elephant in the ground: Managing oil and sovereign wealth.” European Economic Review 82: 113-131. https://doi.org/10.1016/j.euroecorev.2015.10.005.

van der Ploeg, Frederick (2010). "Aggressive oil extraction and precautionary saving: Coping with volatility." Journal of Public Economics 94: 421-433. https://doi.org/10.1016/j.jpubeco.2010.02.005.

van der Ploeg, Frederick and Anthony J. Venables (2011). "Harnessing windfall revenues: optimal policies for resource-rich developing countries." The Economic Journal 121: 1-30. https://doi.org/10.1111/j.1468-0297.2010.02411.x.

van der Ploeg, Frederick and Anthony J. Venables (2012). "Natural resource wealth: The challenge of managing a windfall." Annual Review of Economics 4: 315-337. https://doi.org/10.1146/annurev-economics-080511-111003.

van der Ploeg, Rick, and Cees Withagen (2015). "Global warming and the green paradox: A Review of adverse effects of climate policies." Review of Environmental Economics and Policy 9(2): 285-303. https://doi.org/10.1093/reep/rev008.

Watkins, G.C. (2002). "Characteristics of North Sea reserve appreciation.” The Quarterly Review of Economics and Finance 42: 335-372. https://doi.org/10.1016/S1062-9769(02)00133-3. 
Appendix 1: Lofoten oil and gas: Expendtitures and extraction paths

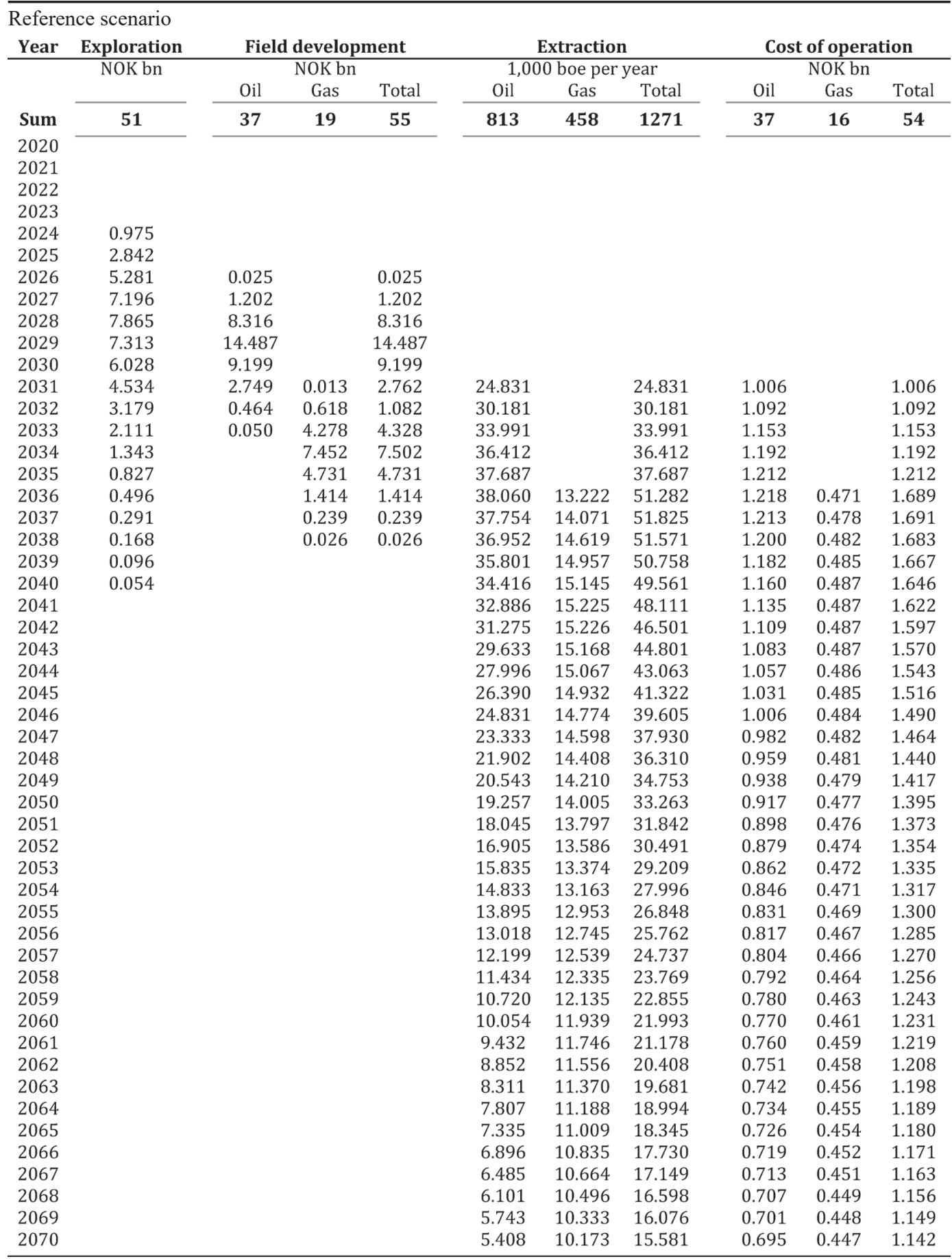

